ISSN: 2146-3042

DOI: $10.25095 /$ mufad.510582

\title{
Standart Maliyet Yönteminin Görsel Haritalama Tekniğine Göre Bibliyometrik Analizi
}

\author{
Enver BOZDEMIR *
}

Figen Çi் $\dot{I}^{* *}$

\begin{abstract}
$\ddot{O Z Z T}$
Çalışmanın amacı maliyetlerin kontrol edilmesini sağlayan standart maliyet yönteminin bibliyometrik analizini yaparak araş̧ırmacılara konuyla ilgili detaylı bilgiler sunmaktır. Bu amaç doğrultusunda standart maliyet yöntemi alanında yapılan 1975-2017 arası araștırmaların durumu ve eğilimleri görsel haritalama tekniği kullanılarak bibliyometrik açıdan analiz edilmiştir. Araștırmada kullanilan veriler, Web of Science veri tabanından derlenmiștir. Çalışma konusu hakkında yazarlar, ülkeler, birlikte yapılan atıflar, kaynaklar, dokümanlar ve terimler arasındaki ilişkileri analiz etmek ve görselleştirmek için VOSviewer yazılımı kullanılmıştır.

Bu yazllim sayesinde standart maliyet konusu metin verisine dayall haritalama ve bibliografik verilere dayalı haritalama analizi yapılmıştır. Bu analiz ile ortak yazarlık, birlikte bulunabilirlik, atıf, bibliyografik eşleştirme, ortak atıf bağı güçlü yazarlar, dokümanlar, kaynaklar, üniversiteler ve ülkeler belirlenmiștir. Bu bulgular sayesinde standart maliyet konusunda yapılacak olan çalı̧̧malar için gerekli kaynaklara daha kolay ve etkin ulaşmada yol gösterebileceği düşünülmektedir. Analizi

Anahtar Kelimeler: Standart Maliyet, Maliyet Yönetimi, Görsel Haritalama Tekniği, Bibliyometrik

JEL Sınıflandırması: M10, M20, M40.
\end{abstract} \section{Techniques}

ABSTRACT

The purpose of the study is to provide detailed information about the subject to the researchers by making a bibliometric analysis of the standard cost method that ensures controlling costs. In accordance with this purpose, the status and trends of research that was done in the field of standard cost method between the years of 1975-2017, was analyzed in terms of bibliometric by using visual mapping technique. The data used in the study was compiled from the Web of Science database. VOSviewer software is used to analyze and visualize the relationships between authors, countries, ascription concerted, sources, documents and term about the study topic.

In virtue of this software, the subject of standard cost is analyzed in compliance with mapping based on text data and mapping based on bibliographic data. Co-authorship, co-existence, ascription, bibliographic matching, writers whose common attribution is strong, documents, resources, universities and countries have been identified with this analysis. By means of these findings, it is thought to show the way to reach the necessary resources more easily and effectively for standard cost studies.

Keywords: Standard Cost, Cost Management, Visual Mapping Technique, Bibliometric Analysis.

Jel Classification: M10, M20, M40.

\footnotetext{
* Doç. Dr., Düzce Üniversitesi İşletme Fakültesi, Sağlık Yönetimi Bölümü, enverbozdemir@ duzce.edu.tr, ORCID ID: 0000-0002-0845-1602

** Düzce Üniversitesi Sosyal Bilimler Enstitüsü, Sağlık Yönetimi Anabilim Dalı, fgncv1646@gmail.com, ORCID ID: 0000-0003-1484-0847
} 


\section{GİRIŞ}

İşletmeler küresel rekabet ortamında yaşamlarını sürdürebilmek için maliyetleri kontrol ederek maliyet liderliğine ve dolaysıyla maliyetlerin yönetimine önem vermek durumundadırlar. Yöneticiler tarafindan maliyetlerin etkin bir şekilde yönetiminde ve kontrolünde geleneksel anlamda standart maliyetleme sistemi kullanılmaktadır.

Bir maliyet kontrol sistemi olan standart maliyet yöntemiyle yöneticiler, istenen performans ile gerçekleşen performans sonuçlarını karşılaştrarak işletmenin arzu edilen amaçlar doğrultusunda faaliyet gösterip göstermediğini belirlemeye çalışırlar. Standart maliyetler, üretim gerçekleşmeden önce bilimsel verilere dayanarak, geçmiş deneyimlere bakılarak ve gelecekteki beklentiler de dikkate alınarak tespit edilir.

Uygulanabilir ve olması gereken maliyetler olarak tanımlanan standart maliyetler aracılı̆̆ı ile işletmede gerçekleşen (fiili) sonuçların planlanan performanstan farklılık (sapma) gösterip göstermediği belirlenir. Eğer ortaya çıkan fiili durum daha önceden belirlenen standartlardan daha fazla ise olumsuz daha az ise olumlu sapma var demektedir. Böylelikle fiili maliyetler ile standart maliyetler arasında fark oluşması durumunda, ortaya çıkan farklar analiz edilerek düzeltici önlemler alınır.

Herhangi bir çalışma alanındaki araştırmacıları kısa bir zamanda en etkin okuma düzeyine ulaştıracak birçok teknikten birisi de bibliyometrik analizdir. Bibliyometrik analiz, literatürün makroskopik olarak incelenmesini sağlayan tekniklerden biridir. Başka bir ifadeyle bibliyometrik analiz, belirli konularda yazılan bilimsel çalışmaların özelliklerini ve atıf durumunu inceleyen niceliksel bir yöntemdir.

$\mathrm{Bu}$ analiz tekniği sayesinde en etkili yazarlar ve yayınlar ve belirli bir konuda öne çıkan dergi, ülke ve kurumlar belirlenebilmektedir. Bu nedenle belirli bir araştırma alanı içerisindeki bilimsel çıktıların özellikleri ve gelişim sürecini takip etmek isteyenler bu analiz yöntemine başvurabilmektedir (Kurutkan ve Orhan, 2018).

Bibliyometri, belirli bir araştırma alanındaki son gelişmeleri, araştırma yönlerini ve önde gelen konularını ortaya çıkarabilmektedir (Wang ve ark. 2014). Ayrıca, bibliyografik analiz, bilimle ilgili karar verme sürecinde önde gelen analizlerden olmakla birlikte dergilerin, ülkelerin ve kurumların performanslarını değerlendirmek amacıyla yaygın bir şekilde kullanılmaktadır (Van Nunen ve ark. 2017).

Başka bir ifadeyle bibliyometrik analiz, belirli konularda yazılan bilimsel çalışmaların özelliklerini ve atıf durumunu inceleyen niceliksel bir yöntemdir. Bibliyometrik analizin önemli bir özelliği çalışılan konu hakkında araştırmacılara detaylı bilgi sunmaktadır. (Kurutkan ve ark., 2017).

Çalışmanın amacı maliyetlerin kontrol edilmesini ve düşürülmesini sağlayan standart maliyet yönteminin bibliyometrik analizini yaparak bilimsel anlamda araştırmacılara konuyla ilgili detaylı bilgiler elde edebilmelerini sağlayan kaynaklar hakkında faydalı bilgiler sunmaktır. Ayrıca bu çalışmayla, araştırmacıların standart maliyet yönteminin dinamik yönlerini tahmin etmeleri ve bu alanda yapılan 1975-2017 arası araştırmalarının durumunu ve eğilimlerini analiz etmeleri amaçlanmıştır. 
Bibliyometrik analize dayalı bu çalışmayla araştırmacılara "standart maliyet" yayınlarının temel özelliklerine ilişkin geniş bir bakış açısı sağlanacaktır. Ayrıca verilen bilgiler, "standart maliyet" alanında elde edilen araştırma ilerlemeleri hakkında net bir resim sunarak araştırmacılara yazar, dergi, ülke, kurum, referans ve araştırma konularından gelen temel başlıkları sunmada yardımcı olacaktır.

\section{VERİ VE YÖNTEM}

Araştırmada kullanılan veriler, Mart 2018'de Web of Science adlı veri tabanından derlenmiştir. Web of Science, ISI (Institute for Scientific Information) Web of Knowledge platformu aracılığıyla ISI Citation Indexes'a internet aracılığıyla erişim hizmeti sunmaktadır. Söz konusu atıf indeksleri (ISI Citation Indexes) dünyanın önde gelen fen bilimleri, sosyal bilimler ile sanat ve insan bilimleri yayınlarından oluşturulan en iyi kalitede araştırma bilgisini sağlamaktadır.

Anılan veri tabanının seçilmesindeki en büyük etken bibliyometrik analiz için gerekli olan verileri en kolay derleyebilen, bilimsel literatürde en çok kabul gören ve sıkça kullanılan veri tabanıdır (Yang ve ark., 2013, Braun ve ark. 2000). Bu veri tabanında yayın ülkeleri, araştırma alanları, dergiler, yazarlar ve anahtar kelimeler gibi bibliyografik göstergelerin performansını analiz etmek için sıklıkla kullanılmaktadır (Zhang ve ark. 2009).

Bu çalışmada kullanılan veriler Thomson Reuters Web of Science, Philadelphia, PA, ABD tarafindan yayınlanan SCI (Science Citation Index) veri tabanına dayanmaktadır. Thomson Reuters ürünü olan Web of Science, uluslararası bir atıf indeksi veri tabanıdır. Veri tabanı günümüzden 1975 yılına kadar giden arşiv koleksiyonu ile konu bazında bilgiye erişim sağladığı için çalışmada 1975'den 2017'ye kadar başlıkları, özetleri ve anahtar kelimeleri aramak için "standard cost" kelimesi kullanılmıştır.

Arama yöntemi ise "standard cost" "standart maliyet" kelimesi ve "topic (konu)" şeklinde gerçekleşmiştir. Konu şeklinde yapılan arama "standard cost" teriminin makale başlığında, özette veya anahtar kelimelerde geçtiği anlamını taşımaktadır. Bu koşul, arama sonuçlarının sağlamlığını garanti etmeye yardımcı olmaktadır. Araştırmada zaman aralığ olarak 1975-2017 arası seçilmiştir.

Eğer aynı arama stratejisi farklı bir tarihte gerçekleştirilirse, sonuçların farklılaşması doğal karşılanmalıdır. Bu farklılıklar, Web of Science'ın sürekli güncellenmesi gerçeğinden ve çalışma alanının sürekli yeni makalelerle desteklenebilmesinden kaynaklanmaktadır (Liu ve ark., 2013).

Web of Science'daki her yayın, yayın yılı, yazarlar, başlık, kaynak, konu kategorileri ve referanslar da dâhil olmak üzere pek çok ayrıntı içermektedir. Web of Science'da depolanmış olan saklanan 303 yayının bu verileri Excel'e aktarılmıştır. Daha sonra yayın sayıları ve büyüme eğilimi, yazarların iş birliği, "standard cost" konusunda yayın yapan dergiler, alıntı analizi, birlikte atıf analizi, konu kategorileri ve terimler gibi başlıklar açısından bibliyometrik analiz gerçekleştirilmiştir.

Yazarlar, ülkeler, birlikte yapılan atıflar, kaynaklar, dokümanlar ve terimler arasındaki ilişkileri analiz etmek ve görselleştirmek için VOSviewer yazılımı (www.vosviewer.com) 
kullanılmıştır. Program; VOS (Visualization of Similarities; Benzerliklerin görselleştirilmesi), haritalama yöntemine dayalı çalışmaktadır. VOS kümeleme yöntemi, kümelenme konularına, her bir kümenin farklı bir renkle işaretlenmesine ve sınıflandırılmasına dayalı çalışmaktadır (Van Eck ve ark. 2010).

Alıntı bağlarının görselinde, renkleri benzer olanların ve birbiri ile çizgisel bağlllı̆̆1 olanların, birbirleri ile olan bağlantı güçleri diğerlerine göre daha yoğundur denilebilir. Şekil ne kadar büyükse, diğerleri ile olan bağlantı gücü o kadar fazladır veya diğerlerinden fazladır yorumunu yapabiliriz. Yoğunluk görselinde ise kırmızı renk yoğunluğu fazla olanın diğerleri ile ilişkisi ve bağlantısı daha fazladır diyebiliriz. Kırmızı rengini sırasıyla sarı, yeşil ve mavi renkleri takip eder. Dairelerin birbirine yakınlı̆g bağlantı güçlerinin kuvvetliliğinin göstergesidir. Eğer daireler birbirine yakın değilse yani renkleri birbirine değmiyorsa aralarında herhangi bir bağlantı ilişkisi bulunmamaktadır yorumunu yapabiliriz.

Başka bir ifadeyle görsellerin yorumu şu şekilde yapılmaktadır: Dairelerin büyüklüğü ve yazı tipi, oluşum sayısının büyüklüğünü, renkler ise kümeleri (kaç sınıfa ayrıldığını) temsil etmektedir. İki daire arasındaki uzaklık, aralarındaki benzerliği ve ilişkiyi ortaya koymaktadır (Khalil ve Gotway Crawford, 2015).

\section{BULGULAR}

Ülkemizde yapılan bilimsel çalışmalarda standart maliyet konusu hakkında yeterli düzeyde çalışmanın yapılmadığı görülmektedir. Kullanılan kaynaklar incelendiğinde çoğunun İngilizce yazılmış olduğu görülmektedir. Bilim kategorisinde mühendislik, sağlık ve ekonomi alanlarında ön plandadır. Dünya genelinde standart maliyeti devamlı olarak kullanan öncü ülkeler arasında Japonya'nın yanı sıra, en fazla çalışma ABD ve İngiltere'de yapılmış̧ır. Türkiye' de ise sadece 3 çalı̧̧ma yapılmış olup ülkeler arası yayın sıralamasında 15. sırada yer almaktadır. Bu da gösteriyor ki gelişmiş ülkelerin bu denli önem verdiği bir yönteme Ülke olarak aynı önem gösterilmeli gereken araştırmalar yapılmalı ve uygulamaya konulmalıdır.

\section{WEB OF SCIENCE CORE COLLECTION VERİ TABANINDA STANDART MALIYET}

\subsection{Disiplinlerarası Standart Maliyet}

Web Of Science Core Collection veri tabanında "Standard Cost" konusunun araştırma alanları aşağıda gösterilmektedir.

Tablo 1. Disiplinler Açısından Standart Maliyetin Çalışıldığ İlk 10 Bilim Alanı

\begin{tabular}{|c|l|c|c|}
\hline No & \multicolumn{1}{|c|}{ Kategori } & Kayıt Sayısı & Toplam Kayda Oranı \% \\
\hline 1 & Ekonomi & 51 & $16.721 \%$ \\
\hline 2 & Sağlık Bilimleri Hizmetleri & 25 & $8.197 \%$ \\
\hline 3 & Yöneylem Araşı̧ıması & 22 & $7.213 \%$ \\
\hline 4 & Sağlık Politikası Hizmetleri Yönetimi & 21 & $6.885 \%$ \\
\hline 5 & Yönetim & 21 & $6.885 \%$ \\
\hline 6 & Elektrik Elektronik Mühendisliği & 19 & $6.230 \%$ \\
\hline 7 & Kamu Çevresel İş Sağlı̆̆ & 19 & $6.230 \%$ \\
\hline 8 & Endüstri Mühendisliği & 17 & $5.574 \%$ \\
\hline 9 & Çevre Çalışmaları & 15 & $4.918 \%$ \\
\hline 10 & Yapay Zeka Bilgisayar Bilimi & 14 & $4.590 \%$ \\
\hline
\end{tabular}


Tablo 1'de görüldüğü üzere standart maliyet konusu en fazla ekonomi, sağl1k bilimleri hizmetleri ve operasyonlar araştırması yönetim bilimidir.

\subsection{Yazarlar ve İş Birlikleri}

Web of Science Core Collection veri tabanında "Standard Cost" konulu yayın çıkaran yazarlara göre bakıldığında Chrıstou, I.T., Lagodimos A.G., Markovic B., Skouri K. ve Tosi A., 3 yayın ile birinci sıradadır. En çok yayın yapan beş yazar ile ilgili bilgiler aşağıdaki gibidir.

Tablo 2. Standart Maliyet Alanında En Fazla Yayın Yapan İlk 5 Yazar

\begin{tabular}{|c|l|l|c|c|c|}
\hline No* & \multicolumn{1}{|c|}{ Yazar Adı } & Ülke & $\begin{array}{c}\text { Yayın } \\
\text { Sayısı }\end{array}$ & $\begin{array}{c}\text { Toplam Kayda } \\
\text { Oranı \% }\end{array}$ & $\begin{array}{c}\text { Yayın Başına } \\
\text { Ortalama Alıntılar }\end{array}$ \\
\hline 1 & Christou, I.T. & Yunanistan & 3 & $1.020 \%$ & 5.3 \\
\hline 1 & Lagodimos, A.G. & Yunanistan & 3 & $1.020 \%$ & 5.3 \\
\hline 1 & Markovic, B. & İtalya & 3 & $1.020 \%$ & 18.6 \\
\hline 1 & Skouri, K. & Yunanistan & 3 & $1.020 \%$ & 18.6 \\
\hline 1 & Tosi, A. & İtalya & 3 & $1.020 \%$ & \\
\hline
\end{tabular}

*Eşit derecede etkin olan yazarlar aynı sıralamaya sahiptir.

Tablo 2'den anlaşıldığı üzere standart maliyet konusunda yayın yapan ilk 5 yazarında 3'er yayınlarının olduğu görülmektedir. Bunun sonucunda çok sayıda ortak yazılmış yayın, aynı alan içindeki yazarlar arasında yakın bir ilişki olduğunu ve gelecekteki işbirliği için daha büyük bir firsat olduğu söylenebilir (Wang ve ark, 2014).

Standart maliyet üzerine yayın yapan yazarların işbirliği (yani ortak yazarlık) VOSviewer ile analiz edilmiştir. Ağdaki yazarlar konuyla ilgili en az yayın yapanlardır. İndirilen verilerdeki yazarlarla bağlantılı olmayan yazarlar bu analize dahil edilmemiştir. $\mathrm{Bu}$ yazarların işbirliği ağının sonucu Şekil 1'de sunulmuştur. Dairelerin büyüklüğü yayın miktarını ve iki yazar arasındaki çizgi aralarındaki işbirliğini temsil etmektedir. Renkler ise, bu alandaki işbirliği kümelerini temsil etmektedir. 


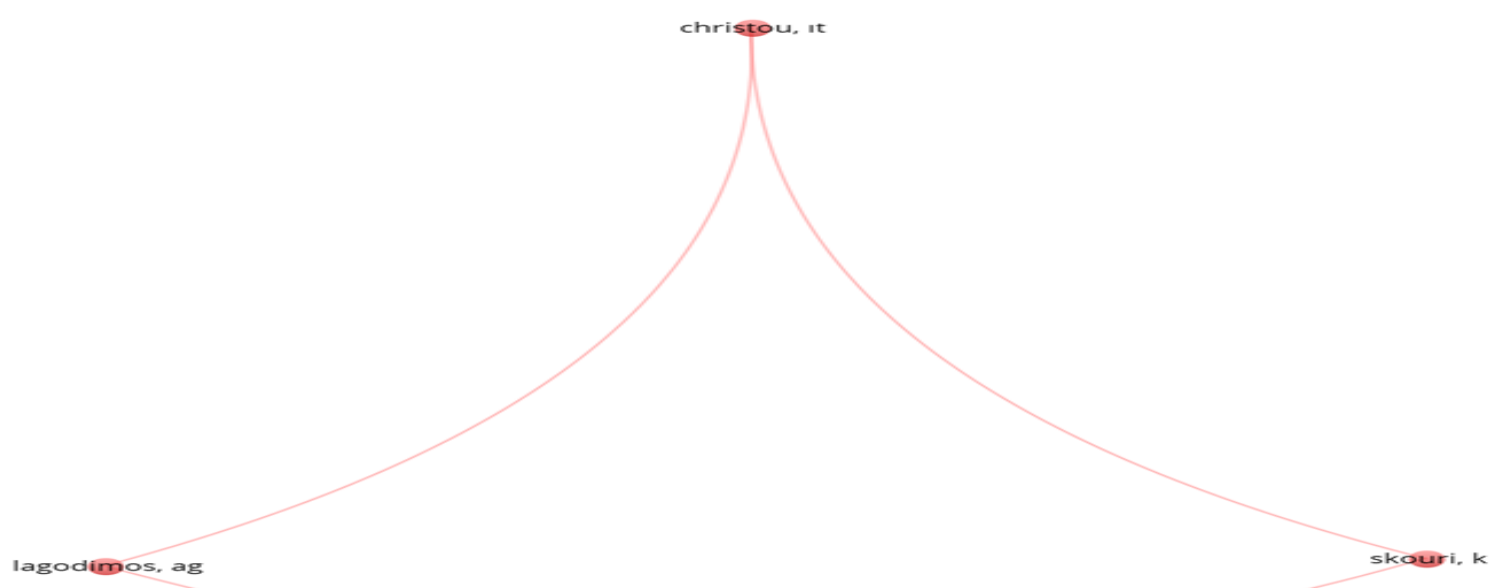

Şekil 1. Yazarların İşbirliği A ̆ğ

Şekil 1'de görüldüğü üzere, işbirliğgi ağında, üç büyük yazarlar kümesi ayırt edilebilir. Ağdaki başlıca araştırmacılar Christou, Lagodimos ve Skouri'dir. Diğer araştırmacılar bu ana araştırmacılardan birine bağlı olanlardır. Chrıstou'ın en fazla bağlantısı olduğu yazarlar Lagodimos ve Skori'dir. Lagodimos' un en fazla bağlantısı olduğu yazarlar Christou ve Skori'dir. Skorı' nin en fazla bağlantısı olduğu yazarlar ise Christou ve Lagodimos'dur.

\subsection{En Çok Yayın Yapan Dergiler}

Web Of Science Core Collection veri tabanında "Standard Cost" konulu en çok yayın yapan dergi, 6 yayın sayısı ile Metalurgia International ve Pharmacoeconomics dergileridir. Konu hakkında yayın yapan ilk 10 dergi aşağıdaki gibidir:

Tablo 3. Standart Maliyet Alanında Yayın Yapan İlk 10 Dergi

\begin{tabular}{|c|l|c|c|c|}
\hline No* & \multicolumn{1}{|c|}{ Derginin Adı } & $\begin{array}{c}\text { Yayın } \\
\text { Sayısı }\end{array}$ & $\begin{array}{c}\text { Toplam Kayda } \\
\text { Oranı \% }\end{array}$ & $\begin{array}{c}\text { Dergi Başına } \\
\text { Ortalama Alıntılar }\end{array}$ \\
\hline 1 & Metalurgia International & 6 & $2.041 \%$ & 0 \\
\hline 1 & Pharmacoeconomics & 6 & $2.041 \%$ & 3,59 \\
\hline 2 & Lecture Notes In Computer Science & 5 & $1.701 \%$ & 1,33 \\
\hline 2 & Value In Health & 5 & $1.701 \%$ & 1,63 \\
\hline 3 & Accounting Review & 3 & $1.020 \%$ & 4 \\
\hline 3 & Energy Policy & 3 & $1.020 \%$ & 1,84 \\
\hline 3 & $\begin{array}{l}\text { International Journal of Production } \\
\text { Economics }\end{array}$ & 3 & $1.020 \%$ & 2,54 \\
\hline 3 & $\begin{array}{l}\text { International Journal of Production } \\
\text { Research }\end{array}$ & 3 & $1.020 \%$ & 1 \\
\hline 3 & $\begin{array}{l}\text { International Journal of Technology } \\
\text { Assessment In Health Care }\end{array}$ & 3 & $1.020 \%$ & 4 \\
\hline
\end{tabular}

*Eşit derecede etkin olan yazarlar aynı sıralamaya sahiptir. 


\section{4. Ülkelere Göre Yayınların Dağılımı}

Web of Science Core Collection veri tabanında "Standard Cost" konulu yayın sayısına en çok katkıda bulunan ilk beş ülke ise sırası ile ABD (115), İngiltere (29), Çin (20), Hollanda (18) ve Kanada'dır (17). Türkiye ise 3 yayın ile 15. sırada yer almaktadır. İlk 10 ülkenin tablosu aşağıdaki gibidir:

Tablo 4. Standart Maliyet Alanında Yayın Yapan İlk 10 Ülke

\begin{tabular}{|c|l|c|c|}
\hline \multirow{2}{*}{ No* } & \multicolumn{1}{|c|}{ Ülkeler } & Kayıt Sayısı & Toplam Kayda Oranı \% \\
\hline 1 & ABD & 111 & $37.755 \%$ \\
\hline 2 & İngiltere & 26 & $8.844 \%$ \\
\hline 3 & Çin Halk Cumhuriyeti & 19 & $6.463 \%$ \\
\hline 4 & Hollanda & 18 & $6.122 \%$ \\
\hline 5 & Kanada & 17 & $5.782 \%$ \\
\hline 6 & Almanya & 16 & $5.442 \%$ \\
\hline 7 & Fransa & 14 & $4.762 \%$ \\
\hline 8 & İtalya & 9 & $3.082 \%$ \\
\hline 9 & Norveç & 8 & $2.721 \%$ \\
\hline 10 & Avusturalya & & \\
\hline
\end{tabular}

\section{5. Önde Gelen Üniversiteler}

Web of Science Core Collection veri tabanında "Standard Cost" konulu yayın çıkaran üniversitelere göre bakıldığında "Centers For Disease Control Prevention USA, Stanford Unıversity, Unıversity Melbourne" 5 yayın ile birinci siradadır. Daha sonra Harvard University 4 yayın ile ikinci sıradadır.

Tablo 5. Standart Maliyet Alanında Yayın Yapan İlk 10 Üniversite

\begin{tabular}{|c|l|c|c|}
\hline No* & \multicolumn{1}{|c|}{ Üniversiteler } & $\begin{array}{c}\text { Kayıt } \\
\text { Sayıs }\end{array}$ & Toplam Kayda Oranı \% \\
\hline 1 & Centers For Disease Control Prevention USA & 5 & $1.701 \%$ \\
\hline 1 & Stanford University & 5 & $1.701 \%$ \\
\hline 1 & University Melbourne & 5 & $1.701 \%$ \\
\hline 2 & Harvard University & 4 & $1.361 \%$ \\
\hline 3 & Athens Informat Technol & 3 & $1.020 \%$ \\
\hline 3 & Duke University & 3 & $1.020 \%$ \\
\hline 3 & Georgia Institute of Technology & 3 & $1.020 \%$ \\
\hline 3 & Hebrew University Jerusalem & 3 & $1.020 \%$ \\
\hline 3 & Military University of Technology in Warsaw & 3 & $1.020 \%$ \\
\hline 3 & Polytechnic University of Milan & 3 & $1.020 \%$ \\
\hline
\end{tabular}

*Eşit derecede etkin olan dergiler aynı sıralamaya sahiptir.

\section{ATIF ANALIZI}

Atıf yapma (Citation) kavramının matbaanın bulunmasından sonra Rönesans döneminde geliştiği bilinmektedir. Atıf yapmanın temel işlevi, atıf yapan ile atıf yapılan belge 
arasında bir bağ kurmaktadır (Al ve Tonta, 2004:21). Diğer bir ifadeyle alıntı yapan kişi ile alıntı yapılan kişi arasındaki ilişki atıf olarak ifade edilmektedir (Gökkurt Demirtel, 1997: 16; At1lgan, 2005: 39).

Atıf sayısının bir yayının nüfuzunu ve şöhretini ve dolayısıyla kalitesini yansıttığ konusunda genel bir ön kabul olduğuna dikkat edilmelidir (Smith, 2007). Bilimsel araştırmanın en önemli amaçlarından biri "diğer araştırmacıları ve alanı etkilemek" olarak ifade edilmektedir. Bir makaleye atıfta bulunmak "etkinin kamu onayının sağlanması" olarak görülürken, olası diğer etkiler nesnel olarak doğrulanmayabilmektedir. Atıfların sadece etkinin ölçülmesinde önemli bir rol oynamadığı unutulmamalıdır, atıflar aynı zamanda bilimsel etkinin bir alt kümesini oluşturmaktadır. Kimi çalışmalara bazen doğrudan yarattıkları entelektüel etki için değil, bazı konulara kazandırdığı meşruiyet nedeniyle atıfta bulunulmaktadır (Atılgan ve ark., 2008: 396).

Bir yayının aldığı atıf sayısı, yayınlanışından bu yana geçen süre ile oldukça ilişkilidir (Qiu ve Chen, 2009). Eski yayınların yeni yayınlara göre daha fazla atıf alma şansı fazladır. Ancak bu durum son yayınlanan çalışmaların bu alandaki önemli bir etkisinin olmayacağ1 anlamina gelmemektedir (Milfont ve Page, 2013).

Web of Science Core Collection veri tabanında "Standard Cost" konusunda en çok atıf alan ilk 20 yayın aşağıdaki gibidir:

Tablo 6. Standart Maliyet Konusunda En Çok Atıf Alan Yazarlar ve Atıf Sayısı

\begin{tabular}{|c|c|c|c|}
\hline Yazarlar & Yayın & Yayın yılı & Atıf sayısı \\
\hline Shampanier, K. ve ark. & Marketing Science & 2007 & 148 \\
\hline Kurniawan, T. ve ark. & Chemical Engineering Journal & 2006 & 129 \\
\hline Mohleboetani, J.C. ve ark. & $\begin{array}{l}\text { Jama-Journal of The American Medical } \\
\text { Association }\end{array}$ & 1993 & 123 \\
\hline Wang, L.Y. ve ark. & Obesity Research & 2003 & 108 \\
\hline Hughes, J.P. ve Mester, L.J. & Review of Economics and Statistics & 1998 & 107 \\
\hline $\begin{array}{l}\text { Howarth, R.B., ve Wilson, } \\
\text { M.A. }\end{array}$ & Land Economics & 2006 & 77 \\
\hline Kivihya-ndugga, lea ve ark. & $\begin{array}{l}\text { International Journal Of Tuberculosis and } \\
\text { Lung Disease }\end{array}$ & 2003 & 69 \\
\hline $\begin{array}{l}\text { Poterba, J. M. ve Summers, } \\
\text { L.H. }\end{array}$ & Sloan Management Review & 1995 & 65 \\
\hline Lenert, L.A. ve ark. & Schizophrenia Research & 2004 & 61 \\
\hline Payne, K.A. ve ark. & Pharmacoeconomics & 2002 & 61 \\
\hline Sojka, R.E. ve Lentz, R.D. & Journal of Production Agriculture & 1997 & 58 \\
\hline Markovic, B. ve ark. & $\begin{array}{l}\text { Ieee Transactions On Circuits And Systems } \\
\text { I-Regular Papers }\end{array}$ & 2013 & 53 \\
\hline
\end{tabular}




\begin{tabular}{|l|l|c|c|}
\hline Wei, J.I.E. ve ark. & $\begin{array}{l}\text { Nuclear Instruments \& Methods In Physics } \\
\text { Research Section A-Accelerators } \\
\text { Spectrometers Detectors And Associated } \\
\text { Equipment }\end{array}$ & 2009 & 51 \\
\hline $\begin{array}{l}\text { Pulley, L.B. ve Humphrey, } \\
\text { D.B. }\end{array}$ & Journal Of Business & 1993 & 51 \\
\hline Kirigia, J.M. ve ark. & Bmc International Health And Human Rights & 2009 & 50 \\
\hline Broecker, J. ve ark. & $\begin{array}{l}\text { Transportation Research Part B- } \\
\text { Methodological }\end{array}$ & 2010 & 49 \\
\hline Skinner, T.E. ve ark. & Journal Of Magnetic Resonance & 2005 & 49 \\
\hline Brown ve ark. & $\begin{array}{l}\text { International Journal of Behavioral Nutrition } \\
\text { And Physical Activity }\end{array}$ & 2007 & 47 \\
\hline Calabrese, J.M. ve ark. & Management Science & 1995 & 44 \\
\hline Overbosch, G.B. ve ark. & Journal Of African Economies & 2004 & 48 \\
\hline
\end{tabular}

En çok atıf alan çalışmalar, 148 adet ile Hampanier, K. ve ark. (2007), 129 adet ile Kurniawan, T. ve ark. (2006), 123 adet ile Mohleboetani, J.C. ve ark. (1993), 107 adet ile Wang, L.Y. ve ark. (2003) ve 107 adet ile Hughes, J.P. ve Mester, L.J. (1998) olmuştur. Anılan yazarlar konu başlıkları açısından sırası ile aşağıdaki konulara yoğunlaşmışlardır;

Hampanier, K. ve ark. (2007) yapmış oldukları "Marketing Science" adlı çalışmada bir malın maliyetinin azaltılması ve aynı zamanda faydasının arttırılmasının tüketiciler üzerindeki psikolojik etkisi incelenmiştir.

Kurniawan, T. ve ark. (2006), yapmış oldukları "Chemical Engineering Journal" adlı çalışmada, depolama sahası sızıntısı için çeşitli ileri oksidasyon teknolojilerinin (AOT) teknik uygulanabilirliği ve arıtma performansı gözden geçirilmiş ve genel olarak, sızıntı suyu arıtımı için en uygun AOT seçimi, sızıntı özelliklerine, teknik uygulanabilirliğe ve potansiyel kısıtlamalara, atık deşarj standardına, maliyet etkinliğine, yasal gerekliliklere ve uzun vadeli çevresel etkilere bağlı olduğu sonucu elde edilmiştir.

Mohleboetani, J.C. ve ark. (1993), yapmış oldukları "Jama-Journal of The American Medical Association" adlı çalışmada İntrapartum antibiyotiklerin erken başlangıçlı neonatal grup B streptokok (GBS) hastalığını önleyebileceği ancak maliyet etkinliği konusundaki belirsizlik için yapılan mali hesaplamaya göre hastalığın önlenmesi için GBS aşılarının geliştirilmesinin ülkeye mali yarar sağlayacağı ve GBS aşısının devam eden gelişimi önemli bir halk sağlığı önceliği olduğu sonucuna ulaşılmıştır.

Wang, L.Y. ve ark. (2003) yapmış oldukları "Obesity Research” adlı çalışmada ortaokul çağındaki çocukların gençliğinde obeziteyi azaltmak için tasarlanan okul temelli bir müdahale olan Planet Health'in maliyet etkinliği ve maliyet-fayda analizi değerlendirilmiştir. 
Son olarak Hughes, J.P. ve Mester, L.J. (1998) tarafindan yapılan "Review of Economics and Statistics" çalışmada ise finansal sermayenin bankacılıktaki rolünü açıklamak için standart maliyet modelinin değiştirilmesi incelenmiştir.

Dergi isimleri her ne kadar standart maliyet konusunu çağrıştırmasa da, "topic" başlı̆̆ adı altında arama yaptı̆̆ımızdan dolayı, dergi ismi ve makale başlığından ziyade, ister mühendislik olsun ister sağlık adı altında yapılmış bir çalışma olsun, içerisinde standart maliyeti konu alan (Web of science Core Collection veri tabanındaki) her çalışmaya değinilmiş̧tir.

Standart maliyet ile ilgili 1999-2017 yılları arası toplam yayınların yayın yılları ve atıf sayıları grafiksel olarak aşağıdaki gibi gösterilmektedir.

Tablo 7. Standart Maliyet ile İlgili Toplam Yayınların Yayın Yılları ve Atıf Sayıları

\section{Yıllara Göre Toplam Yayın Sayısı}

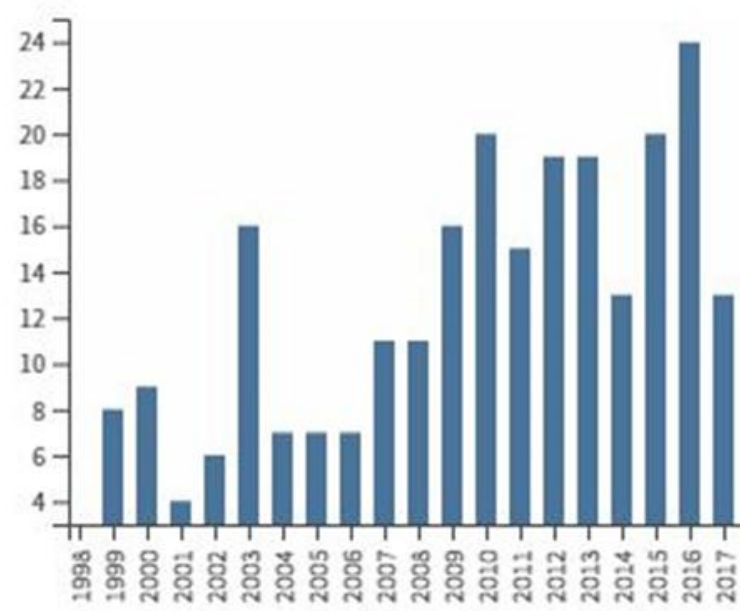

Yıllara Göre Toplam Atıf Sayısı

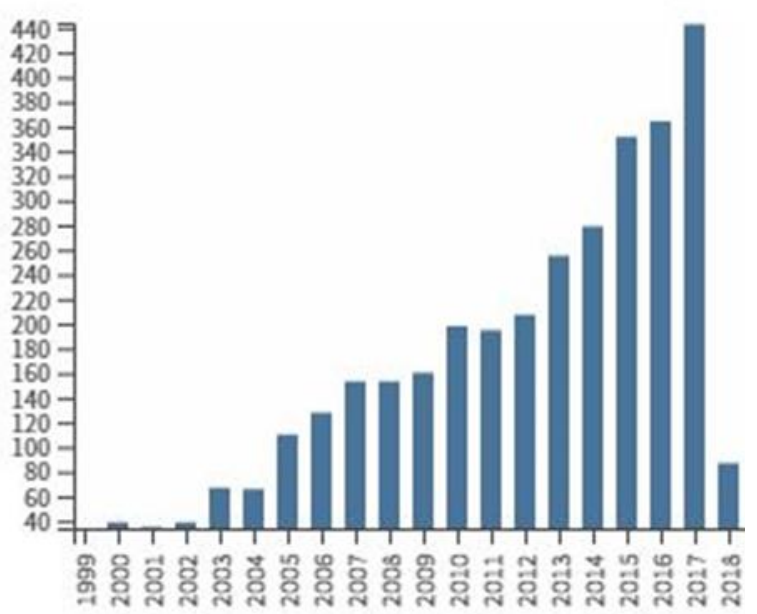

Tablo 7 incelendiğinde standart maliyet alanında yapılan çalışmaların 1999 yılında yayınlanmaya başladığı ve istikrarlı bir artış izlemediği halde özellikle 2013, 2015, 2016 ve 2017 yıllarında yayın sayılarının ciddi bir artış gösterdiği görülmektedir. Atıf sayılarının ise yıllar içinde istikrarlı bir şekilde arttığı görülmektedir.

\section{ORTAK YAZARLIK}

Ortak yazarlıkta bireyler, Simon'un (1972) "sınırlı rasyonellik" kavramında öne sürdüğü gibi sınırlı uzmanlıklara, becerilere ya da kaynaklara sahiplerdir. Bilim insanları için bu kıstı ortadan kaldırmanın yollarından birisi, bilimsel anlamda işbirliği yapmaktır. Bu şekilde araştırmacılar, ortak bir amaç için bir araya gelerek iş yükü paylaşımında bulunurlar. $\mathrm{Bu}$ anlamda uzmanlıklarını, bilgilerini, becerilerini ve kaynaklarını paylaşırlar. Özellikle 2000'li yıllarla birlikte araştırmacılar daha fazla bilimsel anlamda işbirliği yapmaya başlamıştır. Bilimsel işbirliğinin yıllar içinde artış göstermesi, birçok disiplin tarafından konunun öneminin fark edilmesine ve konuya olan ilginin artmasına neden olmuştur. Veri tabanlarına rahat bir şekilde ulaşılabilmesi de yayınlarda ortak yazarlılığı arttırmıştır. Bu bilgilerden hareketle ortak yazarlılık, "iki veya daha fazla bilim insanı arasında bilimsel 
yayının tamamlanabilmesi için sosyal bağlamda, karşılıklı olarak görev paylaşımı şeklinde gerçekleşen etkileşimler” olarak tanımlanabilir (Sayğan Tunçay ve Sürgevil Dalkılıç, 2017).

\subsection{Yazarlar}

Programda (VOSviewer) yazarlarının doküman sayısı program tarafindan minimum 3 seçilerek 711 yazarın 5' i eşik değeri karşılamaktadır. Yazarlar açısından alıntı bağlarının ve yoğunluk görseli aşağıdaki gibidir.
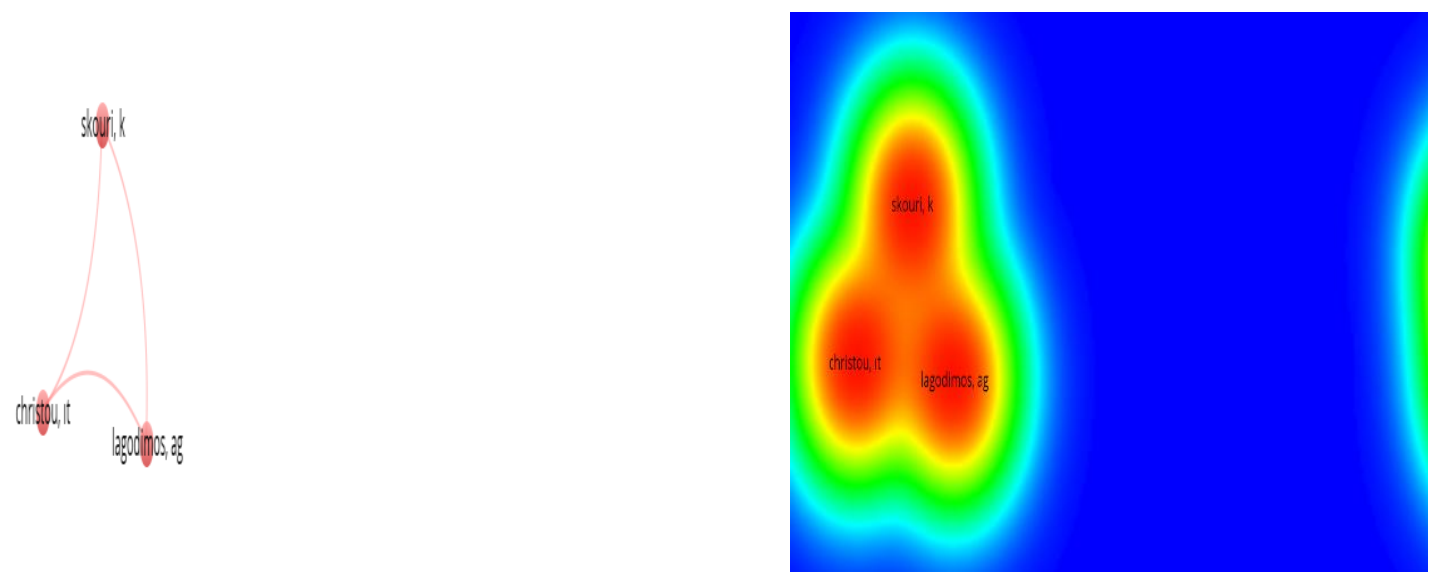

Şekil 2. Yazarlar Açısından Alıntı Bağlarının ve Yoğunluk Görseli

Şekil 2'deki görselde Skouri'nin en fazla bağlantısı olduğu yazar Christou ve Lagodimos'dur. Christou'nun en fazla bağlantısı olduğu yazar Skouri ve Lagodimos'dur. Lagodimos'un en fazla bağlantısı olduğu yazar Christou ve Skouri'dir. Tosi'nin en fazla bağlantısı olduğu yazar Markovic'tir. Markovic'in de en fazla bağlantısı olduğu yazar ise Tosi'dir. Buna göre Skouri, Christou ve Lagodimos' un birbirleri arasındaki bağlantı gücü ile Tosi ve Markovic' in birbirleri arasındaki bağlantı gücü diğer yazarlara göre daha fazladır.

\subsection{Organizasyonlar}

Programda (VOSviewer) organizasyonların alıntılanan doküman sayısı program tarafindan minimum 3 seçilerek 327 organizasyonun 9' u eşik değeri karşılamaktadır. Organizasyonlar açısından alıntı bağlarının ve yoğunluk görseli aşağıdaki gibidir. 

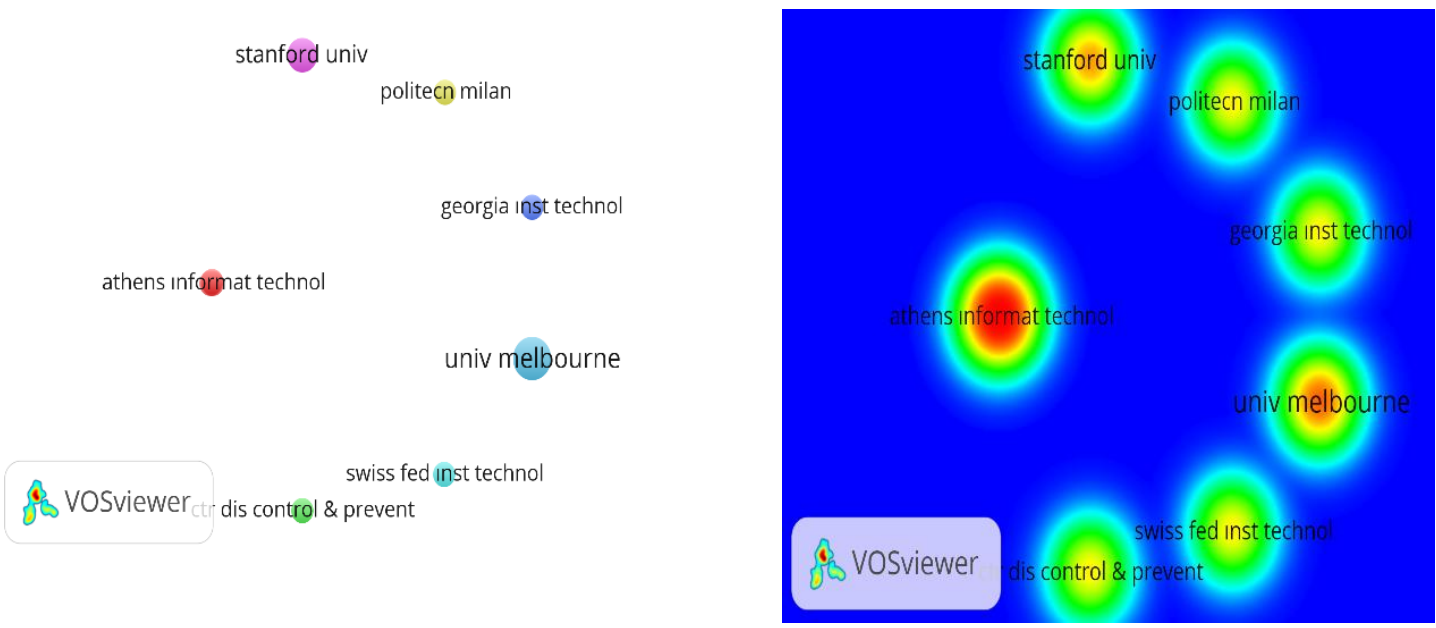

Şekil 3. Organizasyonlar Açısından Alıntı Bağlarının ve Yoğunluk Görseli

Şekil 3'te yer alan her iki görsele de bakıldığında hiçbir üniversitenin birbiri ile bağlantısı olmadığı görülmektedir. Buna göre alıntısı en fazla yapılan organizasyon Athens Informat Technol'dür. Bunu sirayla University Melbourne ve Stanford University takip etmektedir.

\section{3. Ülkeler}

Programda (VOSviewer) ülkelerden alıntılanan doküman sayısı program tarafından minimum 5 seçilerek 47 organizasyonun 13' ü eşik değeri karşılamaktadır. Ülkeler açısından alıntı bağlarının ve yoğunluk görseli aşağıdaki gibidir.
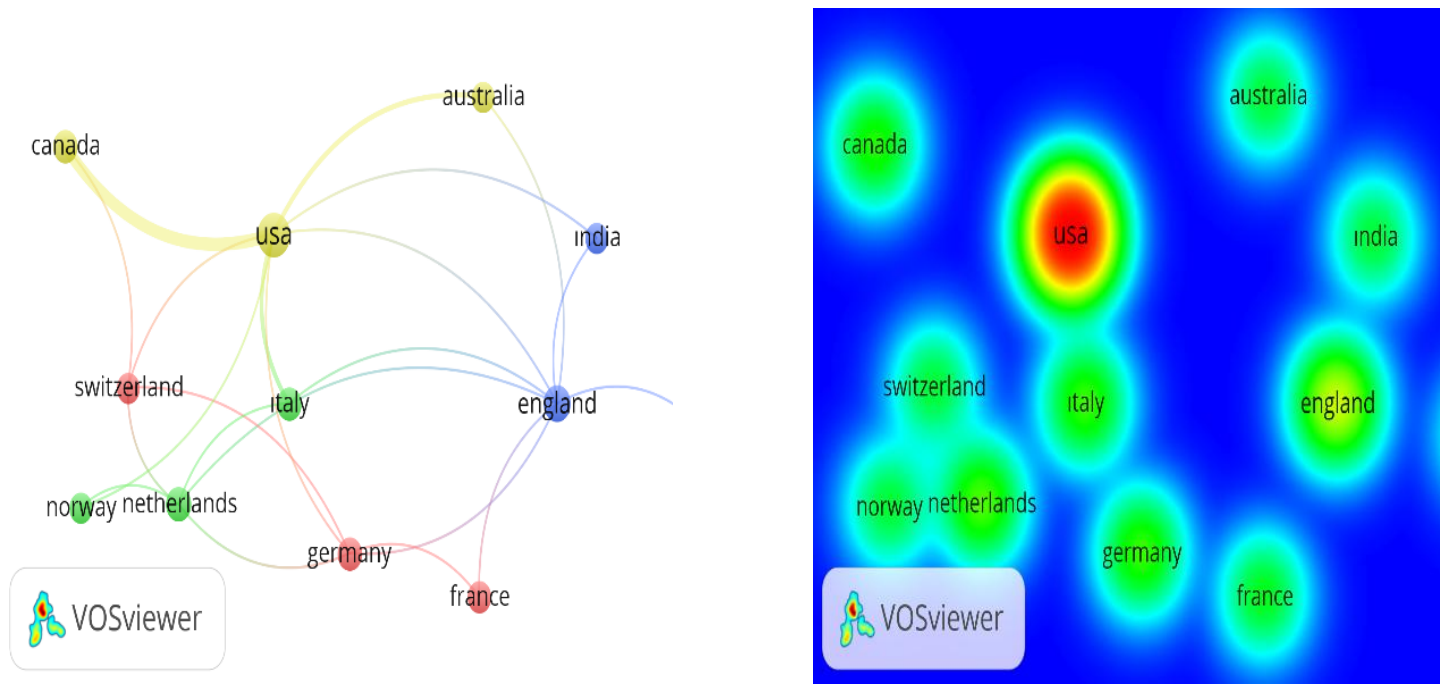

Şekil 4. Ülkeler Açısından Alıntı Bağlarının ve Yoğunluk Görseli 
Şekil 4'te yer alan görsele göre eş yazarlıkta en fazla işbirliği yapılan, alıntısı yapılan ülke ABD'dir. ABD'den sonra İngiltere gelmektedir. ABD'den alıntı ve ortak yazarlık yapan ülkeler; Avusturalya, Kanada, İngiltere, Almanya, Hindistan, Norveç ve İtalya'dır. İngiltere' den alıntı ve ortak yazarlık yapan ülkeler ise; ABD, Hindistan, Hollanda, Almanya, Fransa ve İspanya'nın olduğu görülmektedir.

Ülkeler arası eş yazarlığı ifade edilecek olursak; ABD ile İtalya arasındaki bağlantı ilişkisi ile Hollanda, İsviçre ve Norveç arasındaki bağlantı ilişkisi diğer ülkelere göre daha fazladır diyebiliriz.

\section{BİRLIKTE BULUNABİLIRLIKK}

\subsection{Yazarların Anahtar Kelimeleri}

Programda (VOSviewer) yazarların alıntılanan doküman sayısı program tarafindan minimum 5 seçilerek 600 organizasyonun 4'ü eşik değeri karşılamaktadır. Yazarların anahtar kelimeleri açısından alıntı bağlarının ve yoğunluk görseli aşağıdaki gibidir.
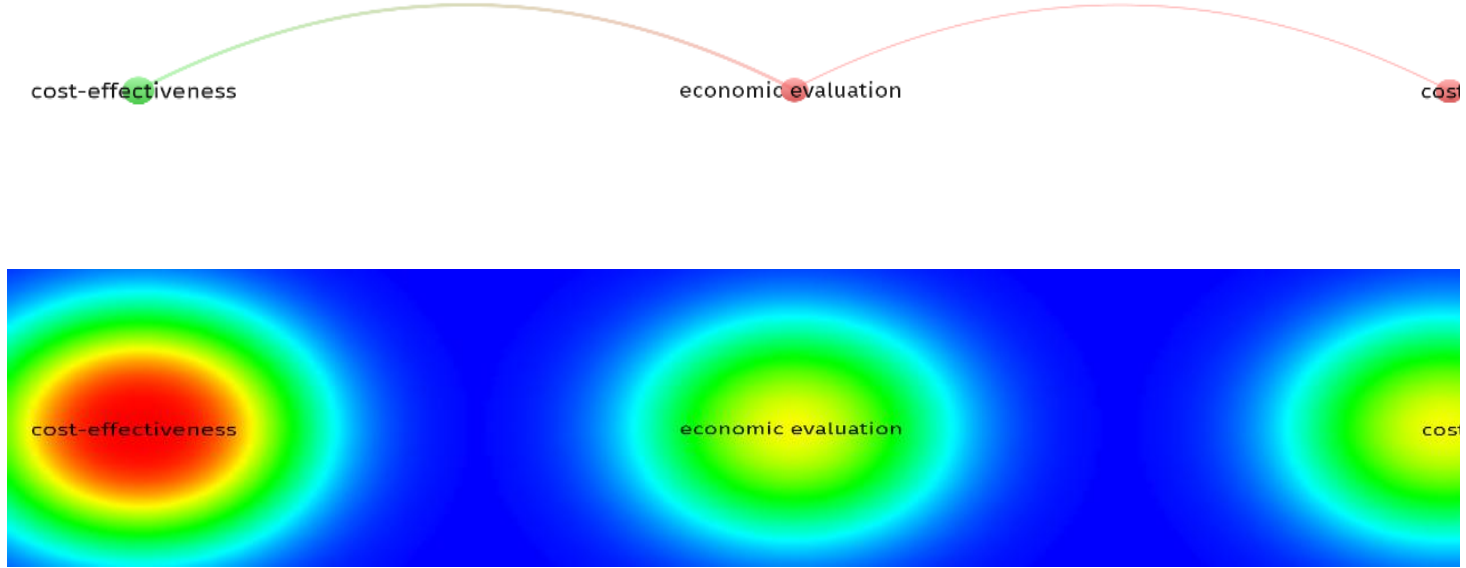

Şekil 5. Yazarların Anahtar Kelimeleri Açısından Alıntı Bağlarının Ve Yoğunluk Görseli

Şekil 5'deki görsele göre en fazla alıntısı yapılan anahtar kelime "cost-effectiveness' dir. Bu kelimenin "economics evaluation" kelimesi ile olan bağlantı gücü diğer kelimelere oranla daha fazladır. "cost-effectiveness" kelimesinin tek başına iken "cost" kelimesi ile bir bağlantısı yoktur. Fakat "economics evaluation" anahtar kelimesinin her iki kelime ile bağlantı gücü eşit ve fazladır. 


\section{ALINTI}

\subsection{Dokümanlar}

Programda (VOSviewer) yazarın alıntılanan doküman sayısı program tarafindan minimum 10 seçilerek 219 yazarın 48'i eşik değeri karşılamaktadır. Dokümanlar açısından alıntı bağlarının ve yoğunluk görseli aşağıdaki gibidir.
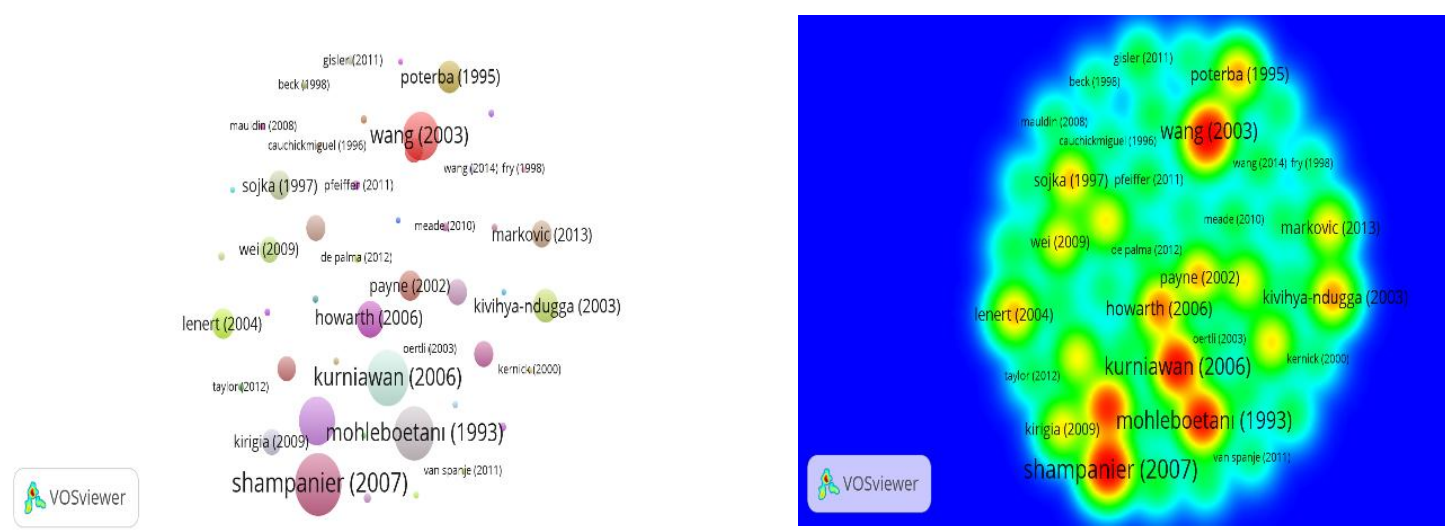

Şekil 6. Dokümanlar Açısından Alıntı Bağlarının ve Yoğunluk Görseli

Şekil 6'daki görselde görüleceği üzere alıntılanan doküman sayısı en fazla olan yazarlar Wang (2003), Shampainer (2007), Mohleboetani (1993) ve Kurniawan (2006) diyebiliriz.

\subsection{Kaynaklar}

Programda (VOSviewer) yazarın minimum alıntı yapılan kaynak sayısı program tarafından 3 seçilerek 201 yazarın 3 'ü eşik değeri karşılamaktadır. Kaynaklar açısından alıntı bağlarının ve yoğunluk görseli aşağıdaki gibidir.

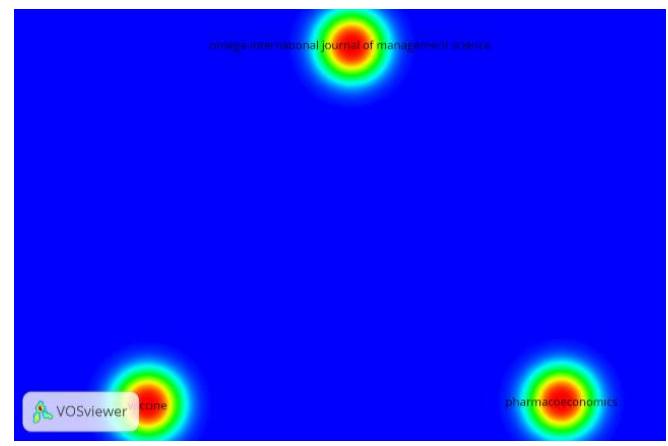

Şekil 7. Kaynaklar Açısından Alıntı Bağları ve Yoğunluk Görseli 
Şekil 7'deki görselde görüleceği üzere alıntı bağlantıları fazla olan kaynaklar; OmegaInternational Journal of Management Science, Vaccine ve Pharmacoeconomics'dir. Yoğunluk görselinde görüldüğü üzere kaynakların 3 farklı gruba ayrıldıkları görülmektedir. $\mathrm{Bu}$ kaynakların birbiri ile bağlantısı yoktur.

\subsection{Yazarlar}

Programda (VOSviewer) minimum alıntı yapılan yazar sayısı program tarafından 3 seçilerek 711 yazarın 5'i eşik değeri karşılamaktadır. Yazarlar açısından alıntı bağlarının ve yoğunluk görseli aşağıdaki gibidir.

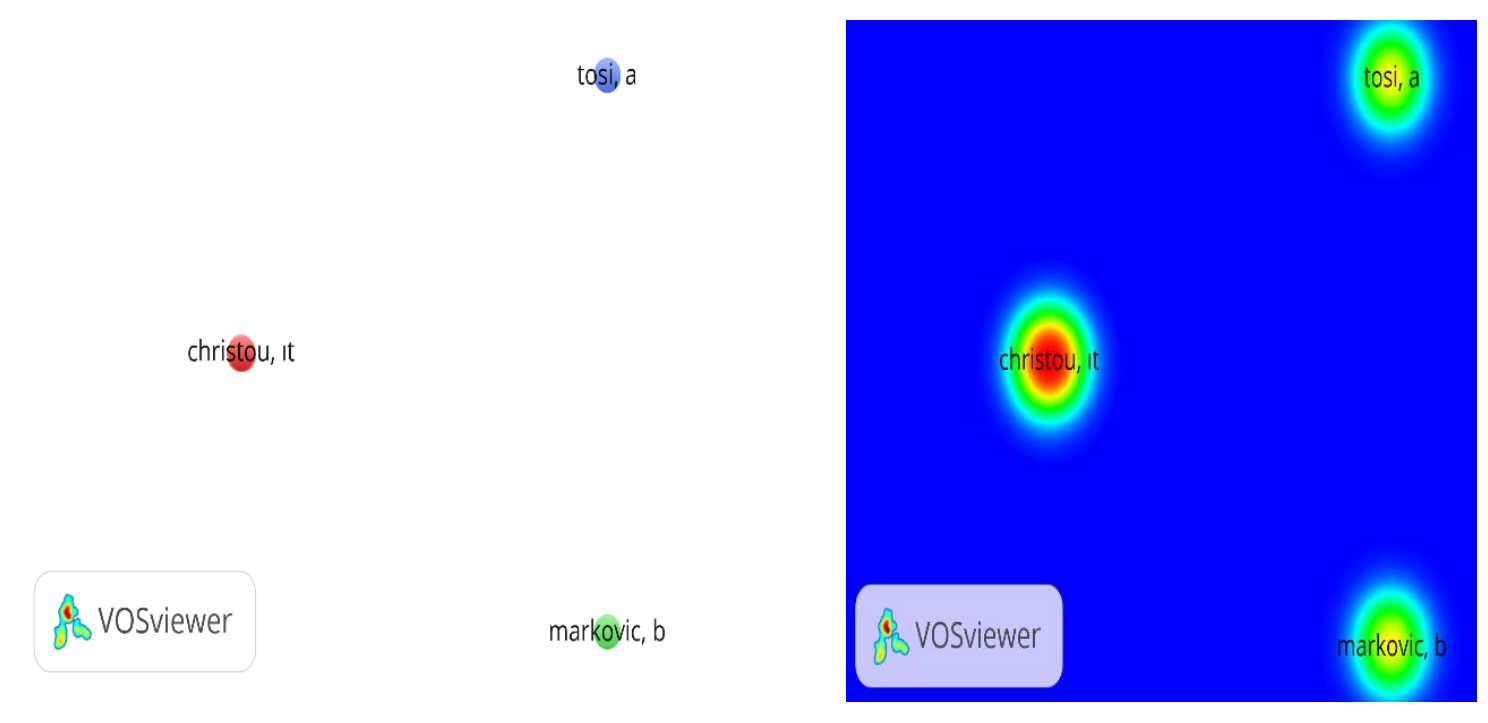

Şekil 8. Kaynaklar Açısından Alıntı Bağlarının ve Yoğunluk Görseli

Şekil 8'deki görselde en fazla alıntısı yapılan yazar; Christou, I.T.'dir. Bunu Markovic, B. ve Tosi, A. takip etmektedir. Görselde de görüleceği üzere yazarların birbirleri ile bağlantıları yoktur.

\subsection{Organizasyonlar}

Programda (VOSviewer) minimum alıntı yapılan organizasyon say1s1 program tarafından minimum 3 seçilerek 327 yazarın 9'u eşik değeri karşılamaktadır. Organizasyonlar açısından alıntı bağlarının ve yoğunluk görseli aşağıdaki gibidir. 
stanford univ

politecn milan

georgia Inst techno

athens informat technol

univ melbourne

swiss fed inst technol

\& VOSviewer dis control \& prevent

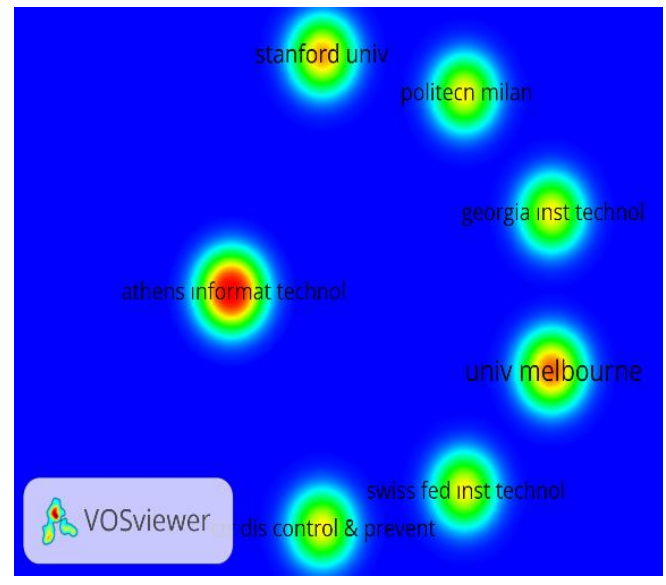

Şekil 9. Organizasyonlar Açısından Alıntı Bağlarının ve Yoğunluk Görseli

Şekil 9'daki görselde alıntısı fazla yapılan organizasyonlar; Athens Imformat Technol, University Melbourne ve Stanford University'dir. Hem bu üç organizasyon arasında hem de diğer herhangi bir organizasyon arasında bağlantı yoktur.

\section{5. Ülkeler}

Programda (VOSviewer) minimum alınt1 yapılan ülke sayısı program tarafindan 5 seçilerek 42 yazarın 13'ü eşik değeri karşılamaktadır. Ülkeler açısından alıntı bağlarının ve yoğunluk görseli aşağıdaki gibidir.
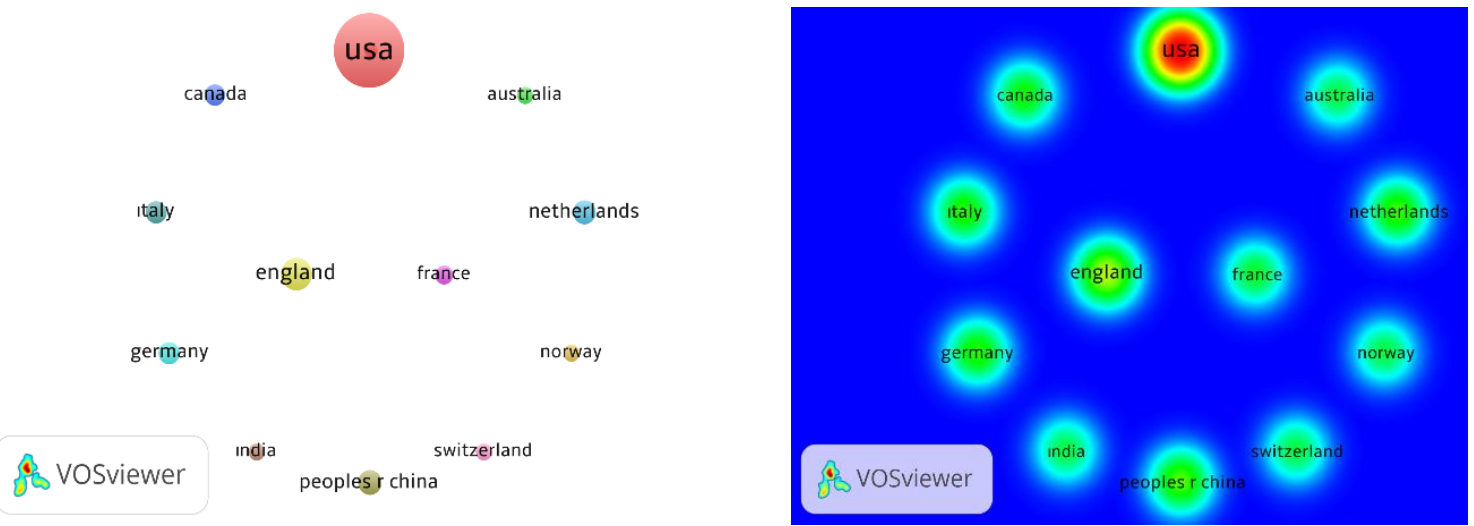

Şekil 10. Ülkeler Açısından Alıntı Bağlarının ve Yoğunluk Görseli

Şekil 10'daki görselde alıntısı en fazla yapılan ülke ABD'dir. ABD'yi takip eden ülke ise İngilteredir. Diğer ülkelerin bağlantı yoğunluğu oldukça düşüktür. Görselden de anlaşılacağı üzere hiçbir ülkenin birbiri ile bağlantısı ve ilişkisi bulunmamaktadır. 


\section{BİBLIYYOGRAFIKK EŞLEŞTİRME}

Atıf analizi çalışmaları çeşitli teknikler kullanılarak gerçekleştirilmektedir. Bu tekniklerin en yaygın kullanım alanı bulanları "bibliyografik eşleştirme" (bibliographic coupling)'dir. Farklı iki kaynakta aynı yayına atıf yapılmasına bibliyografik eşleştirme denmektedir (Al ve Tonta, 2004).

\subsection{Dokümanlar}

Programda (VOSviewer) yazarın minimum doküman sayısı program tarafından 10 seçilerek 219 yazarın 48'i eşik değeri karşılamaktadır. Dokümanlar açısından alıntı bağlarının ve yoğunluk görseli aşağıdaki gibidir.
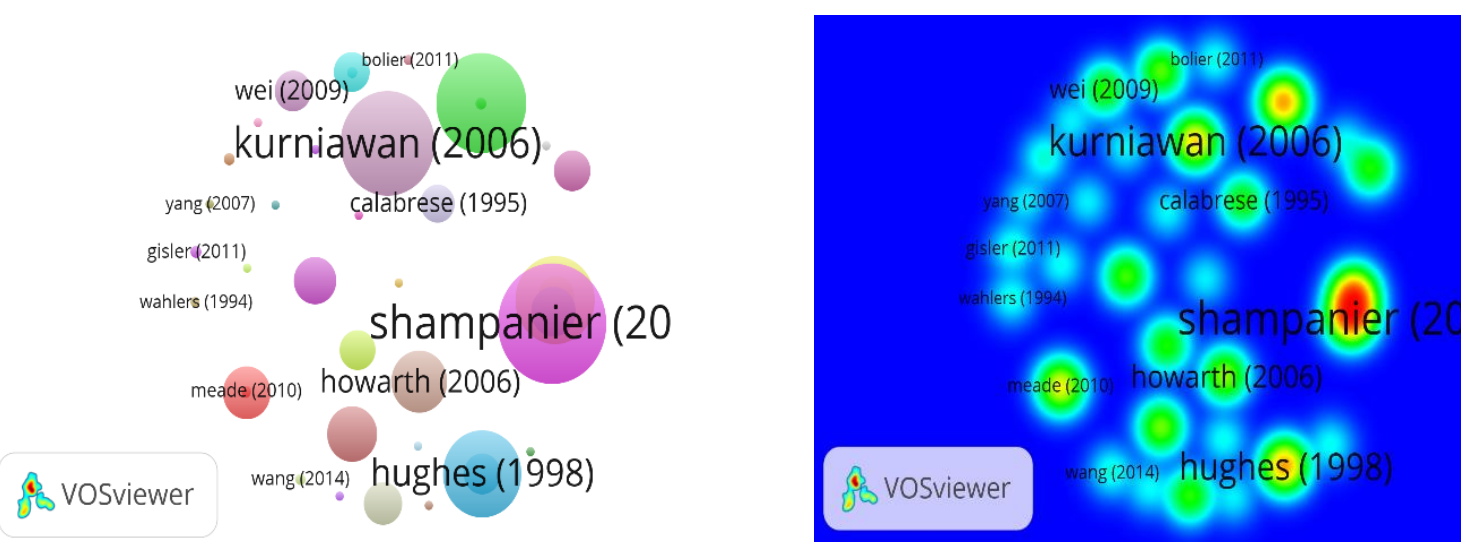

Şekil 11. Dokümanlar Açısından Alıntı Bağlarının ve Yoğunluk Görseli

Şekil 11'deki görselde yazarın bağlantı gücü en fazla olan dokümanı Shampanier (2007)'dir. Mohleboetanı (1993) ikinci sırada ve bunu bağlantı güçleri birbirine çok yakın olan Kurniawan (2006) ve Hughes (1998) takip etmektedir. Bağlantı gücü en az olanlara örnek verecek olursak; Yang (2007), Gisler (2011) ve Wahlers (1994)' i örnek verebiliriz.

\subsection{Kaynak}

Bir yazarın kaynak sayısı program tarafından minimum 1 seçilerek 201 kaynağın 201' i bu eşik değeri karşılamaktadır. Kaynaklar açısından alıntı bağlarının ve yoğunluk görseli aşağıdaki gibidir. 

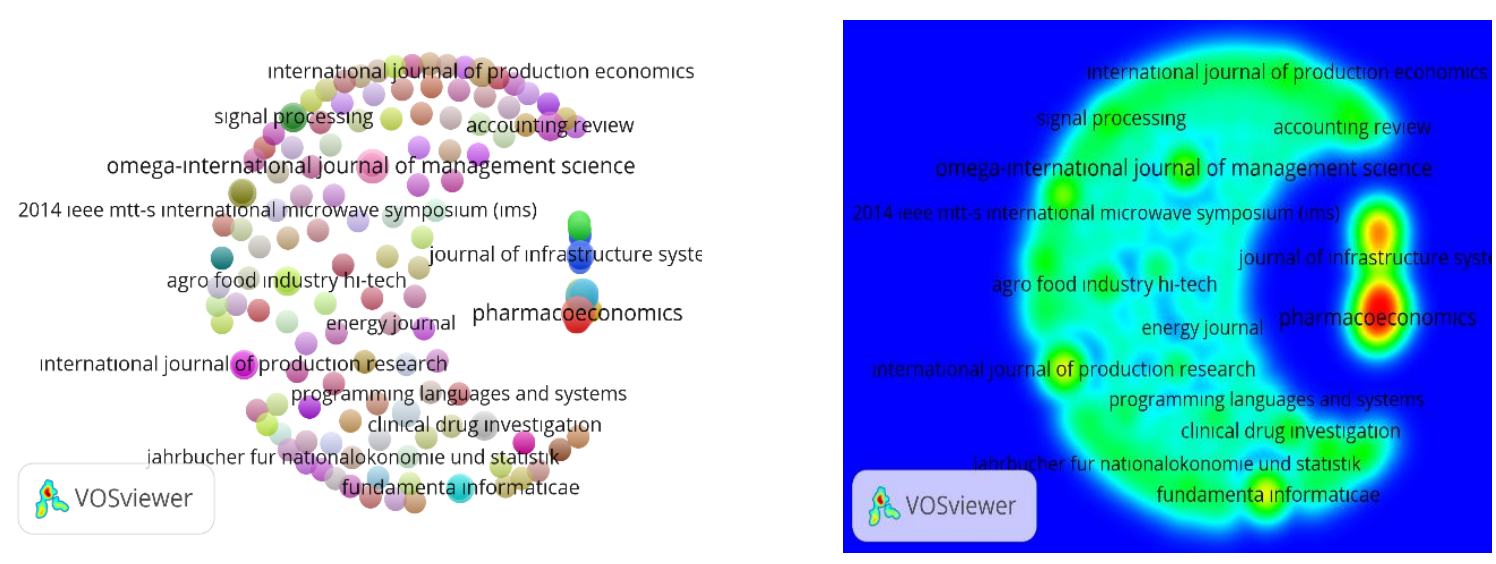

Şekil 12. Kaynaklar Açısından Alıntı Bağlarının ve Yoğunluk Görseli

Şekil 12'deki görselde Pharmacoeconomics ile Journal of Infrasructure Systems kaynaklarının arasındaki bibliyografik eşleştirme bağlantı gücü, diğerleri ile olan bağlantı gücüne göre daha fazladır. Bağlantı gücü en fazla olan kaynak Pharmacoeconomics' dir. Görseldeki renk yoğunluğundan da anlaşılacağı üzere bunu ikinci olarak Journal of Infrasructure Systems takip etmektedir.

\subsection{Yazarlar}

Programda (VOSviewer) yazarın minimum doküman sayısı program tarafindan minimum 3 seçilerek 711 yazarın 5'i eşik değeri karşılamaktadır. Yazarlar açısından alıntı bağlarının ve yoğunluk görseli aşağıdaki gibidir.

christou, it

skouri, k

\& vosviewers, ag

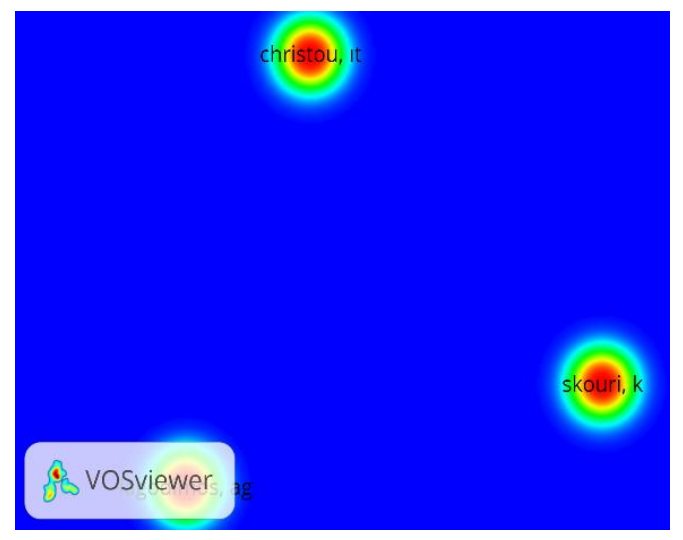

Şekil 13. Yazarlar Açısından Alıntı Bağlarının ve Yoğunluk Görseli

Şekil 13'deki görselde bibliyografik eşleştirme bağlantısı en güçlü olan yazarlar Christou, I.T., Skouri, K. ve Lagodimos, A.G. 'dir. Aralarındaki uzaklığın fazla olması bu üç yazar arasında bir ilişkinin olmadığını göstermektedir. 


\subsection{Organizasyonlar}

Programda (VOSviewer) organizasyonun minimum doküman sayısı program tarafindan 3 seçilerek 327 organizasyonun 9'u eşik değeri karşılamaktadır. Organizasyonlar açısından alıntı bağlarının ve yoğunluk görseli aşağıdaki gibidir.

swiss fed inst technol
politecn milan georgia inst technol

ctr dis control \& pre

athens informat technol

fes vosviewer

univ melbourne

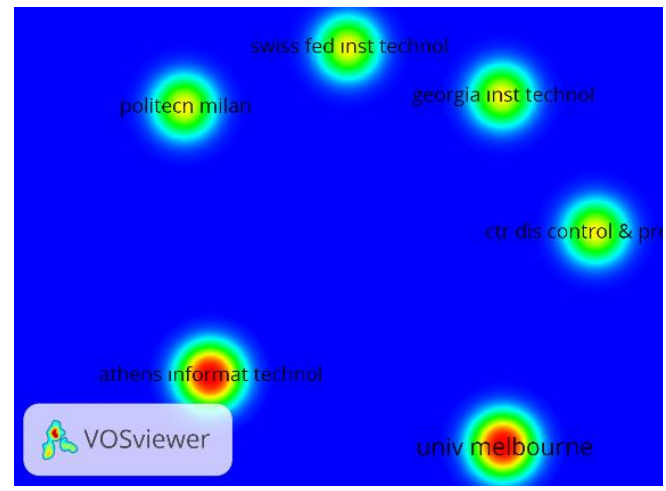

Şekil 14. Organizasyonlar Açısından Alıntı Bağlarının ve Yoğunluk Görseli

Şekil 14'deki görselde bibliyografik eşleştirme bağı en yüksek organizasyonlar sırasıyla; University Melbourne, Athens Informat Technol ve bağlantı güçleri birbirine eşit olan görseldeki diğer dört üniversitedir.

\section{5. Ülkeler}

Programda (VOSviewer) ülkelerin minimum doküman sayısı program tarafindan 5 seçilerek 47 ülkenin 13'ü eşik değeri karşılamaktadır. Organizasyonlar açısından alıntı bağlarının ve yoğunluk görseli aşağıdaki gibidir.
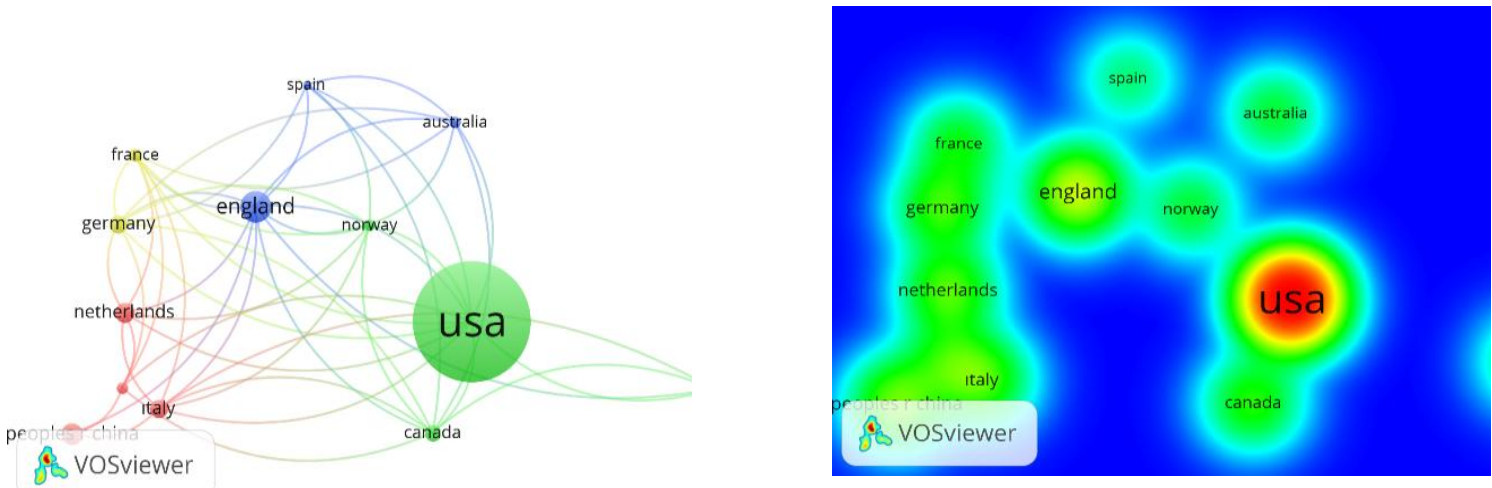

Şekil 15. Organizasyonlar Açısından Alıntı Bağlarının ve Yoğunluk Görseli 
Şekil 15'deki ağ bağlarının görselinde; bibliyografik eşleştirme bağı gücü en fazla olan ülke ABD'dir. ABD ile bağlantıda olan ülkeler; Kanada, Hindistan, Norveç, İtalya, İngiltere, Avusturalya, İspanya, Fransa, Almanya ve Hollanda'dır. Yoğunluk görselinde ise, ABD ile Kanada arasındaki bağ diğer ülkelere göre daha fazladır. Fransa, Almanya, Hollanda, İtalya ve Çin arasındaki bağ da diğer ülkelerle olan bağlarına göre fazladır denilebilir.

\section{ORTAK ATIF ANALIZI}

Atıf analizi çalışmaları çeşitli teknikler kullanılarak gerçekleştirilmektedir. $\mathrm{Bu}$ tekniklerin en yaygın kullanım alanı bulanları "bibliyografik eşleştirme" (bibliographic coupling) ve "ortak atıf"tır (co-citation). Farklı iki kaynakta ayn yayına atıf yapılması bibliyografik eşleştirme, bir kaynakta farklı iki yayına atıf yapılması ise ortak atıf olarak tanımlanmaktadır (Al ve Tonta 2004:23).

\subsection{Atıf Yapılan Referanslar}

Atıfta bulunulan referansın asgari sayıdaki alıntı sayısı program tarafından 5 seçilerek 5.983 atıfta bulunulan referansların 3 tanesi eşik değerini karşılamaktadır. Atıf yapılan referanslar açısından alıntı bağlarının ve yoğunluk görseli aşağıdaki gibidir.
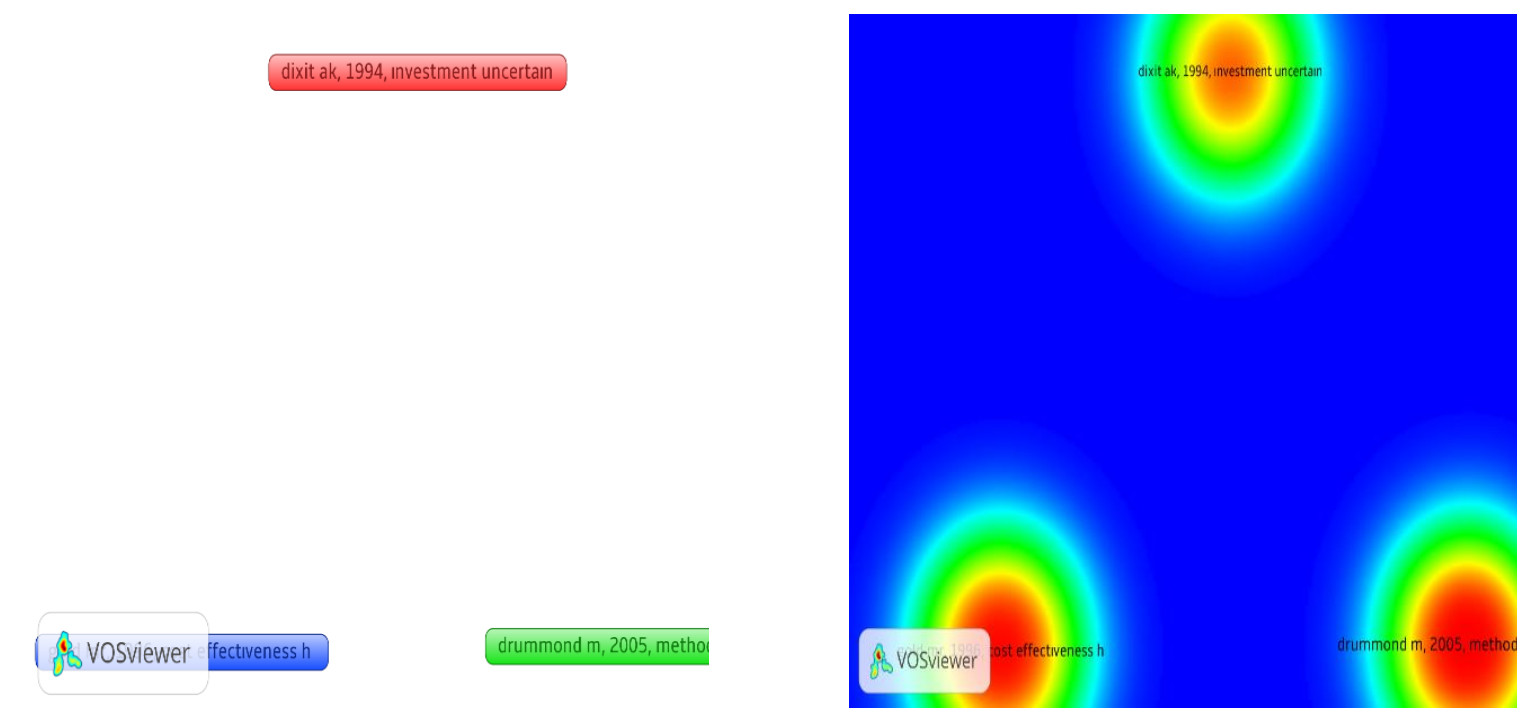

Şekil 16. Atıf Yapılan Referanslar Açısından Alıntı Bağlarının Ve Yoğunluk Görseli

Şekil 16'daki görselde en fazla atıf yapılan referanslar sırasıyla; Drummond, Gold ve Dixit'dir. Bu üç referans arasında herhangi bir bağlantı ve atıf ilişkisi bulunmamaktadır.

\subsection{Atıf Yapılan Kaynaklar}

Atıfta bulunulan kaynakların asgari sayıdaki alıntı sayısı program tarafindan 20 seçilerek 3376 kaynağın 26'sı eşik değerini karşılamaktadır. Atıf yapılan kaynaklar açısından alıntı bağlarının ve yoğunluk görseli aşağıdaki gibidir. 

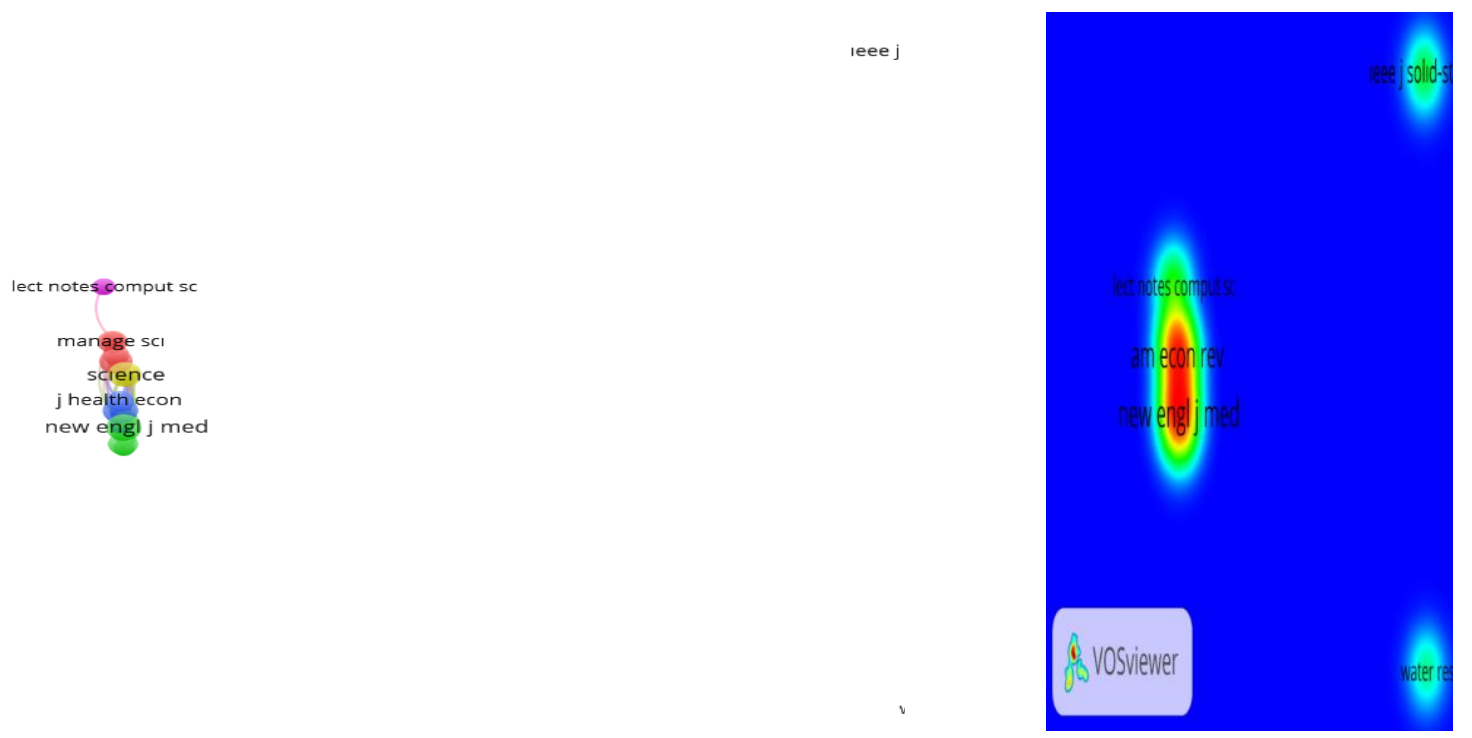

Şekil 17. Atıf Yapılan Referanslar Açısından Alıntı Bağlarının ve Yoğunluk Görseli

Şekil 17'deki görselde en fazla atıf yapılan kaynaklara örnek verecek olursak; Canadian Journal of Economics-Revue, Canadienne D Economique, Journal of Health Economics ve Management Science'dir. Bu kaynakların birbiri arasındaki bağlantı gücü, diğer kaynaklarla olan ilişkilerine göre daha fazladır. Journal of Water Resources Planning and Management-Asce ise en az atıf yapılan kaynaklar arasındadır ve diğer kaynaklarla herhangi bir bağlantısı yoktur.

\subsection{Atıf Yapılan Yazarlar}

Alıntı yapılan yazarların asgari sayıdaki alıntı sayısı program tarafından 13 seçilerek 4805 alıntı yapılan yazarın 4'ü eşik değerini karşılamaktadır. Atıf yapılan yazarlar açısından alıntı bağlarının ve yoğunluk görseli aşağıdaki gibidir.

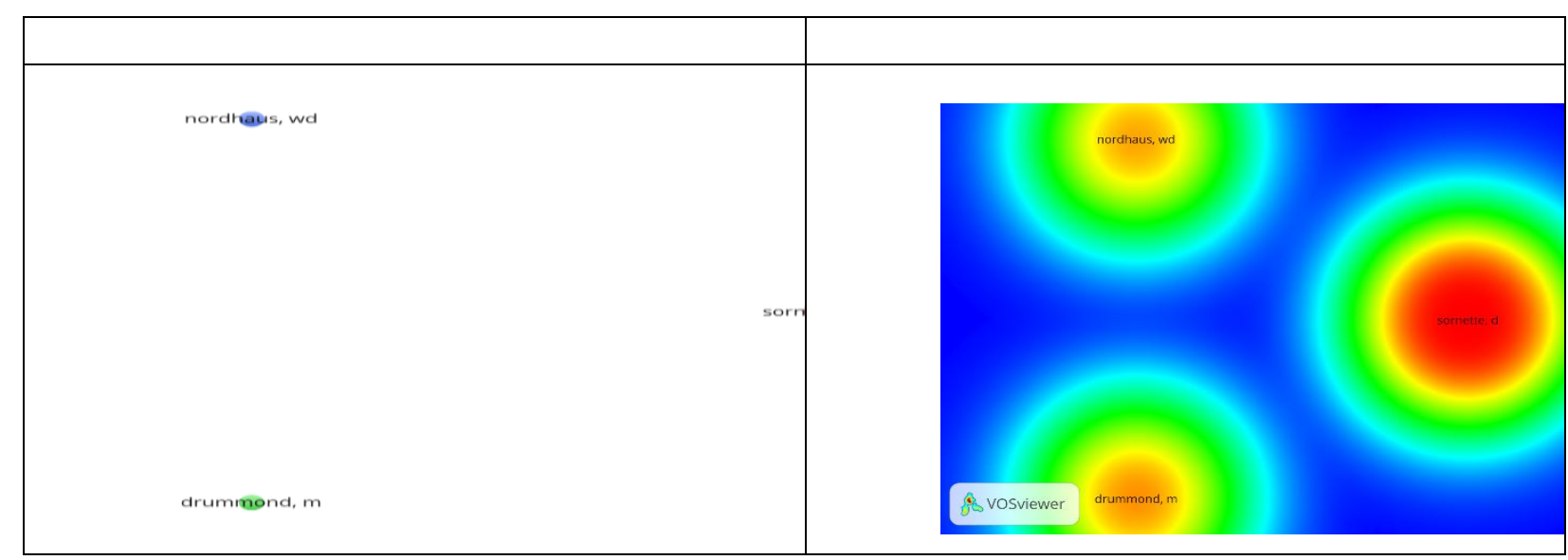

Şekil 18. Atıf Yapılan Yazarlar Açısından Alıntı Bağlarının Ve Yoğunluk Görseli 
Alıntısı en fazla yapılan yazarlar sirasıyla; Sornette, Drummond ve Nordhaus' dur. Görselden de anlaşılacağı üzere üç yazar arasında herhangi bir atıf ilişkisi bulunmamaktadır.

\section{KONU KATEGORILERI}

Standart maliyet konusunda yapılan çalışmalarda en çok kullanılan terimlerin tespiti için VOSviewer programındaki metin verisine dayalı haritalama kullanılmıştır. Programdaki eşik değer 10 seçilmiştir. 45.591 terimin 234'ü bu eşik değeri karşılamaktadır. Bu 1.000 kelime arasında konu başlığı ile (\%60) ilgili terimler (140) seçilmiştir. Analiz sonucunda en çok kullanılan terimler sağlık, ingiltere, problem, maliyet etkinliği, kalite, teknoloji, standart maliyet, uygulama, bakım, bilim, ekonomi ve uygulama terimleridir. Konu kategorileri açısından alıntı bağlarının ve yoğunluk görseli aşağıdaki gibidir.
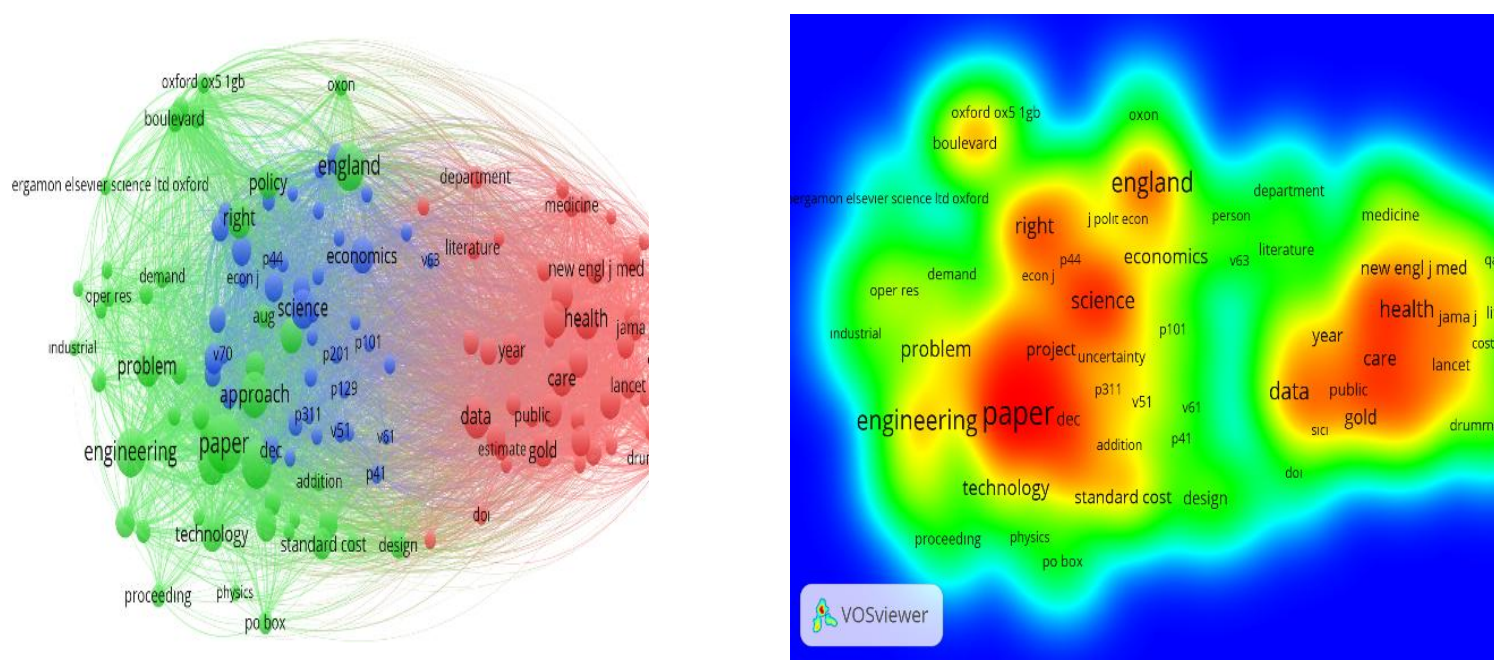

Şekil 19. Konu Kategorileri Açısından Alıntı Bağlarının ve Yoğunluk Görseli

Şekil 19'daki görselde, dairelerin büyüklüğü bir terimin oluşumunu temsil etmekte, yani boyut arttıkça, "Standard Cost" konulu yayınların özetlerinde ve başlıklarında bir terimin oluşumu daha yüksektir. Terimler arasındaki toplam mesafe, ilişkileri hakkında bilgi verir. Terimler arasındaki uzaklık ne kadar kısa olursa, ilişkileri o kadar güçlüdür. Terimlerin birbirine bağlılığı, başlıkların ve özetlerin içinde birlikte geçen ifadelerin sayılması sayesinde belirlenmektedir. Renkler ise farklı kümeleri ayırt etmek için kullanılır (Rodrigues ve ark., 2014). En çok kullanılan kelime "paper" kelimesidir ama tek başına bir önem ve anlam ifade etmediği için ikinci en yoğun renkli kelimeyi "health" i dikkate alırız. Health kelimesini "care", "science" ve "project" takip etmektedir. En fazla kullanılan kelimenin diğer kelimeler ile bağlantısı şu şekildedir:

Health kelimesinin bağlantılı olduğu kelimeler: care, science, economics, medicine, standard cost, quality, design kelimeleridir. Kullanılan terimler en azdan çoğa doğru mavi, yeşil, sarı, turuncu ve kırmızı renkleri ile yoğunluk görselinde görselleştirilmiştir. Renklendirmeden de görüldüğü üzere en az kullanılan kelimeler de mavi renklerde görüldüğü üzere oxon, department, physics kelimeleridir. 


\section{SONUÇ}

Standart maliyet konulu çalışmaların atıf, bibliyografik eşleştirme, ortak yazarlılık, ortak oluşum ve ortak atıf analizleri yapılırken Web of Science Core Collection veri tabanında standart maliyet konulu yapılan çalışmaların analizi için "VOSviewer" programı kullanılmıştır.

Standart maliyet konusu VOSviewer programında Metin Verisine Dayalı Haritalama ve Bibliografik Verilere Dayalı Haritalama Analizi yapılmıştır. İlk olarak metin verisine dayalı haritalamada "standart maliyet" konulu çalışmalarda en çok kullanılan terimler bulunmuştur. Daha sonra Bibliyografik Verilere Dayalı Haritalama yapılarak atıf, bibliyografik eşleştirme, ortak yazarlılık, ortak oluşum ve ortak atıf analizleri kullanılmıştır. $\mathrm{Bu}$ sayede ortak yazarlık, birlikte bulunabilirlik, atıf, bibliyografik eşleştirme, ortak atıf bağ güçlü yazarlar, dokümanlar, kaynaklar, üniversiteler ve ülkeler belirlenmiştir. Bu bulguların standart maliyet konusunda yapılacak olan çalışmalar için gerekli olan kaynakları bulmada yol gösterebileceği düşünülmektedir. Yapılan araştırma sonucunda; doküman, kaynak, yazar, organizasyon ve ülke bağlantı gücü en yüksek ilk 5 olmak üzere tablo yardımı ile aşağıda gösterilmektedir.

Yapılan bibliyometrik analiz çalışmasının bazı kısıtları bulunmaktadır. Yapılan arama Web of Science'da sonuçlanan yayınlarla sınırlıydı. Web of Science, bilimsel yayınların analizi için en çok kabul gören ve sıkça kullanılan veri tabanı olmasına rağmen elbette "standart maliyet" alanındaki tüm yayınları içermemektedir. Bibliyometrinin bir diğer kısıtlaması da, analizin yalnızca Web of Science'da bulunan mevcut sınıflandırmalar için yapılabilmesidir. Bibliyometrik analizin ayırıcı niteliklerini ortaya koyan bu kısıtlamaları dikkate alarak, benzer ya da daha ileri araştırmalar için daha önce yayınlanmış çalışmaların içerik analizine tabi tutulması göz önünde bulundurulması tavsiye edilebilir. 
The Journal of Accounting and Finance- January/2019

(81): $59-84$

\begin{tabular}{|c|c|c|c|c|c|c|}
\hline Analiz Tipi & $\begin{array}{l}\text { Analiz } \\
\text { Birimi }\end{array}$ & 1 & 2 & 3 & 4 & 5 \\
\hline \multirow{3}{*}{$\begin{array}{c}\text { Co-authorship } \\
\text { (Ortak } \\
\text { yazarlılık) }\end{array}$} & $\begin{array}{c}\text { Authors } \\
\text { (Yazarlar) }\end{array}$ & CHRISTOU, IT & LAGODIMOS, AG & SKOURİ, K & MARKOVIC, B & TOSI, A \\
\hline & Organization & ATHENS INFORMAT TECHNOL & UNIVERSITY PIRAEUS & UNIVERSITY IOANNINA & $\begin{array}{l}\text { CENTERS FOR DISEASE } \\
\text { CONTROL PREVENTION } \\
\end{array}$ & $\begin{array}{l}\text { GEORGIA INSTITUTE OF } \\
\text { TECHNOLOGY } \\
\end{array}$ \\
\hline & Countries & USA & ENGLAND & CANADA & GERMANY & NETHERLANDS \\
\hline $\begin{array}{c}\text { Co-occurrence } \\
\text { (Ortak } \\
\text { olusum) } \\
\end{array}$ & $\begin{array}{l}\text { Author } \\
\text { Keywords }\end{array}$ & ECONOMIC EVALUATION & COST-EFFECTIVENES & costs & COST-BENEFIT ANALYSIS & - \\
\hline \multirow{5}{*}{$\begin{array}{l}\text { Citation } \\
\text { (Attf) }\end{array}$} & Documents & WANG (2003) & LAGODIMOS (2012a) & LAGODIMOS (2012b) & LAGODIMOS (2012c) & GRAZIOSE (2017) \\
\hline & Sources & PHARMACOECONOMICS & $\begin{array}{l}\text { INTERNAIONAL JOURNAL OF } \\
\text { PRODUCTION ECONOMICS }\end{array}$ & $\begin{array}{l}\text { OMEGA-INTERNAIONAL JOURNAL } \\
\text { OF MANAGEMENT SCIENCE }\end{array}$ & $\begin{array}{l}\text { INTERNAIONAL JOURNAL } \\
\text { OF PRODUCTION } \\
\end{array}$ & VACCINE \\
\hline & Author & MARKOVIC, B & TOSI, A & CHRISTOU, IT & LAGODIMOS, AG & SKOURİ, K \\
\hline & Organization & $\begin{array}{c}\text { CENTERS FOR DISEASE } \\
\text { CONTROL PREVENTION USA } \\
\end{array}$ & $\begin{array}{l}\text { POLYTECHNICUNIVERSITY OF } \\
\text { MILAN } \\
\end{array}$ & UNIVERSITY MELBOURNE & $\begin{array}{l}\text { ATHENS INFORMAT } \\
\text { TECHNOL }\end{array}$ & UNIVERSITYY PIRAEUS \\
\hline & Countries & USA & CANADA & PEOPLES R CHINA & NETHERLANDS & GERMANY \\
\hline \multirow{5}{*}{$\begin{array}{l}\text { Bibliographic } \\
\text { Coupling } \\
\text { (bibliyografik } \\
\text { eşleştirme) }\end{array}$} & Documents & WANG (2003) & BROWN (2007) & MAULDİN (2008) & FRY (1998) & PAYNE (2002) \\
\hline & Sources & VACCINE & PHARMACOECONOMICS & $\begin{array}{c}\text { INTERNATIONAL JOURNAL OF } \\
\text { ENVIRONMENTAL RESEARCH AND }\end{array}$ & VALUE IN HEALTH & ACCOUNTING REVIEW \\
\hline & Author & CHRISTOU, IT & LAGODIMOS, AG & SKOURİ, K & MARKOVIC, B & TOSI, A \\
\hline & Organization & ATHENS INFORMAT TECHNOL & UNIVERSITY PRAEUS & UNIVERSITY IOANNINA & STANFORD UNIVERSITY & $\begin{array}{l}\text { UNIVERSITY } \\
\text { MELBOURNE }\end{array}$ \\
\hline & Countries & USA & ENGLAND & NETHERLANDS & CANADA & ITALY \\
\hline \multirow{3}{*}{$\begin{array}{l}\text { Co- Citation } \\
\text { (Ortak Atıf) }\end{array}$} & $\begin{array}{c}\text { Cited } \\
\text { References }\end{array}$ & DRUMMOND, M (2005) & WEINSTEIN, MC (1977) & ARROW, KJ (1970) & DixiT, AK (1994) & GOLD, MR (1996) \\
\hline & Cited Sources & DİABETES CARE & AM J OBSTET GYNECOL & NEW ENGL J MED & BRIT MED J & SCIENCE \\
\hline & Cited Authors & ROBERTS, L & SORNETTE, D & DRUMMOND, M & EBERBACH, E & NORDHAUS, WD \\
\hline
\end{tabular}




\section{KAYNAKLAR}

Al, U. -Tonta, Y. (2004). "Atıf Analizi: Hacettepe Üniversitesi Kütüphanecilik Bölümü Tezlerinde Atıf Yapılan Kaynaklar”, Bilgi Dünyası, 5 (1), ss.19-47.

Atılgan, D.- Atakan, C. - Bulut, B. (2008). "Türkçe Kütüphanecilik Dergilerinin Atıf Analizi. Türk Kütüphaneciliği”, Cilt 22, Sayı 4, ss. 392-413.

Braun, T., Schubert, A. P. ve Kostoff, R. N. (2000), "Growth and Trends of Fullerene Research As Reflected In Its Journal Literature”, Chemical Reviews, 100(1), pp.2337.

Gökkurt Demirtel, Ö. (1997). "Citation” Indeks ve "Citation” Analizi: Enformatik Bir Model Çalışması”, Yayınlanmamış Doktora Tezi, Ankara Üniversitesi, Bilgi ve Belge Yönetimi Bölümü Ankara. (http://bbytezarsivi.hacettepe.edu.tr/jspui/handle/2062/129, Erişim tarihi: 01/04/2018).

Khalil, G. M., ve Crawford, C. A. G. (2015). "A Bibliometric Analysis of U.S.-Based Research on the Behavioral Risk Factor Surveillance System", American Journal of Preventive Medicine, 48(1), pp.50-57.

Kurutkan, M.N. ; Orhan, F. ve Kaygısız, P. (2017). "Hasta Güvenliği Literatürünün Bibliyometrik Analizi: Türkçe Tez ve Makaleler Örneği”, Sağlık Akademisyenleri Dergisi. Cilt 4, Say1 4, ss.253-259.

Kurutkan, M.N. ve Orhan, F. (2018). Kalite Prensiplerinin Görsel Haritalama Tekniğine Göre Bibliyometrik Analizi. Sage Yaymevi. Ankara.

Liu, X., Zhan, F. B., Hong, S., Niu, B. ve Liu, Y. (2013). "Replies to comments on "a bibliometric study of earthquake research: 1900-2010", Scientometrics, 96(3), pp.933936.

Milfont, T. L. ve Page, E. (2013). "A bibliometric review of the first thirty years of the Journal of Environmental Psychology”, Psyecology, 4(2), pp.195-216.

Qiu, H. ve Chen, Y. F. (2009). "Bibliometric Analysis of Biological İnvasions Research During the Period of 1991 to 2007”, Scientometrics, 81(3), pp.601-610.

Sayğan Tunçay, S. ve Sürgevil Dalkılıç, O. (2017). "Yönetim ve Organizasyon Bilim Alanında Ortak Yazarlılık", Journal of Business Research-Türk, 9/3, 393-423.

Smith, D. R. (2007). "Historical Development of the Journal İmpact Factor and Its Relevance for Occupational Health", Industrial Health, 45(6), pp.730-742.

Van Eck, N. J., Waltman, L., Dekker, R., ve Vanden Berg, J. (2010), “A Comparison of Two Techniques For Bibliometric Mapping: Multidimensional Scaling and VOS", Journal of The American Society For Information Science and Technology, 61(12), pp.24052416. 
Van Nunen, K., Li, J., Reniers, G., ve Ponnet, K. (2017), "Bibliometric Analysis of Safety Culture Research”, Safety Science, http://dx.doi.org/10.1016/j.ssci.2017.08.011.

Wang, B., Pan, S. Y., Ke, R. Y., Wang, K., ve Wei, Y. M. (2014). "An Overview of Climate Change Vulnerability: A Bibliometric Analysis Based on Web of Science Database", Natural Hazards, 74(3), pp.1649-1666.

Yang, L., Chen, Z., Liu, T., Gong, Z., Yu, Y. ve Wang, J. (2013), "Global Trends of Solid Waste Research From 1997 to 2011 by Using Bibliometric Analysis", Scientometrics, 96(1), pp.133-146.

Zhang, W. W., Qian, W. H. ve Ho, Y. S. (2009). "A bibliometric analysis of research related to ocean circulation", Scientometrics, 80(2), pp.305-316.

www.vosviewer.com 